\title{
Bryophytes and macro-algal growths as a part of macrophyte monitoring in rivers used for ecological assessment
}

\author{
P. Baláži ${ }^{(1), \star}$, R. Hrivnák ${ }^{(2)}$ \\ Received April 19, 2015 \\ Revised June 5, 2015 \\ Accepted June 23, 2015
}

\section{ABSTRACT}

Key-words:

aquatic

macrophyte,

IBMR,

river,

Slovakia,

Water Framework

Directive

Altogether, 62 taxa of macrophytes including 18 bryophytes and 16 macro-algal growths were determined at 87 survey sites (73 rivers) representing the both ecoregions in Slovakia (Pannonian and Carpathian) during the years 2010-2013. Bryophytes represented the dominant community in the Carpathians, while the occurrence of macro-algal growths was relatively balanced in both ecoregions. Ordination analyses (DCA) showed an obvious shift within studied survey sites from vascular plants to bryophytes, while macro-algal growths were more or less uniform distributed in the whole ordination space. Based on stepwise (forward) selection in CCA, altitude and water surfaces as a land use type were the main environmental factors responsible for this pattern and explained $13.7 \%$ of the variability. Variation partitioning showed that the shares of environmental variables on the total variation decreased in the following order: both groups together $8.3 \%$ (landscape and geographical variables, physicochemical variables), followed by landscape and geographical variables (5.8\%) and purely physicochemical variables which had an insignificant effect on macrophyte composition. The importance of both groups (bryophytes and macro-algal growths) in ecological assessment was also confirmed by their contribution to the mean IBMR value determined for each water body type. Anyway, our study showed that their contribution to ecological assessment is not focused only on small mountain streams where they are dominant. They may obviously affect ecological assessment also in many water body types in lowland rivers and large upland rivers as well.

\section{RÉSUMÉ}

Le développement des bryophytes et des macro-algues comme partie de la surveillance des macrophytes utilisées pour l'évaluation écologique en rivières

Mots-clés : macrophytes aquatiques, IBMR, rivière, Slovaquie,
Au total, le développement de 62 taxons de macrophytes dont 18 bryophytes et 16 macro-algues a été déterminé dans 87 sites de sondage (73 rivières) représentant les deux écorégions de Slovaquie (Pannonienne et des Carpates) au cours des années 2010-2013. Les bryophytes représentaient la communauté dominante dans les Carpates, tandis que l'occurence des macro-algues était relativement équilibrée dans les deux écorégions. Les analyses d'ordination (DCA) ont

(1) Water Research Institute, L. Svobodu 5, 81249 Bratislava, Slovak Republic

(2) Institute of Botany, Slovak Academy of Sciences, Dúbravská cesta 9, 84523 Bratislava, Slovak Republic

* Corresponding author: balazi.peter@gmail.com 
Directive Cadre sur l'Eau montré un changement évident dans les sites de l'étude des plantes vasculaires vers les bryophytes, tandis que le développement des macro-algues était plus ou moins uniformément distribué. Basé sur une sélection progressive pas à pas en CCA, altitude et surfaces en eau comme le mode d'utilisation des terres ont été les principaux facteurs environnementaux responsables de cette tendance, expliquant $13,7 \%$ de la variabilité. Le partitionnement de la variabilité a montré que la part des variables environnementales sur la variation totale a diminué dans l'ordre suivant : les deux groupes ensemble (8,3 \%) (variables du paysage et géographiques, variables physico-chimiques), suivis par le paysage et les variables géographiques $(5,8 \%)$ et les variables purement physico-chimiques qui avaient un effet négligeable sur la composition des macrophytes. L'importance de ces deux groupes (bryophytes et macro-algues) dans l'évaluation écologique a également été confirmée par leur contribution à la valeur IBMR moyenne déterminée pour chaque type de masse d'eau. Quoi qu'il en soit, notre étude a montré que leur contribution à l'évaluation écologique ne se concentre pas uniquement sur les petits ruisseaux de montagne où ils sont dominants. Ils peuvent évidemment avoir aussi une incidence sur l'évaluation écologique dans de nombreux types de cours d'eau, dans les rivières de plaine comme dans les grandes rivières de montagne.

\section{INTRODUCTION}

Rivers represent important aquatic habitats for human race from the economy point of view and have been utilized historically since a very long time. In addition, their biological importance is high; rivers are a place for various organisms including macrophytes. Therefore, the research of macrophyte distribution in rivers and their relation to environmental conditions has been a subject of researcher interest relatively for long (Hrivnák et al., 2013; Szoszkiewicz et al., 2014; Žuna Pfeiffer et al., 2015). The main factors and processes controlling the status of macrophytes in rivers are hydrology characteristics such as water velocity, seasonal and inter-annual dynamics of water regime, discharge, and furthermore light, substrate, nutrients, competition and river management practices (Franklin et al., 2008; Lacoul and Freedman, 2006). However, the effects of geomorphology and climate are important as well (Lacoul and Freedman, 2006).

Different groups of macrophytes are influenced by different environmental factors. For example, higher flow velocity and relatively more stable coarse-grained sediment type are typical of bryophytes presence (Ceschin et al., 2012; Downes et al., 2003; Hrivnák et al., 2010). On the contrary, increased abundance of vascular plants is closely related to slow water flow and fine-grained bottom material (Haslam, 2006). River algae grow in heterogeneous lotic habitats from springs to large rivers with various ecological conditions (Janauer and Dokulil, 2006). In the last years, attention paid to the river macrophyte research was focused on macrophytes as a tool for the assessment of ecological status. According to the European Standard EN 14184:2014, larger plants of fresh water which are easily seen with naked eye or which usually form colonies belong to aquatic macrophytes, including all aquatic vascular plants, bryophytes, stoneworts and macro-algal growths. After requirements of the EU Water Framework Directive (WFD) 2000/60/EC (European Union, 2000) and according to the abovementioned European Standard, bryophytes and macro-algal growths should be included in the assessment of ecological status. In some European countries they are both included in the method of ecological status assessment based on macrophytes, e.g. Belgium/Flanders (Leyssen et al., 2005), France and Belgium/Wallonia (Haury et al., 2006), Great Britain (Willby et al., 2009), Poland (Szoskiewicz et al., 2006), Slovakia (NV SR 269/2010 Z. z.). Mainly in the case of macro-algal growths, in some countries they are a part of ecological status assessment based on phytobenthos, e.g. Austria, the Czech Republic, Germany, Norway (Kelly, 2013). According to the WFD, macrophytes and phytobenthos comprise one biological quality element. The applicability of different plant groups can be more or less restricted due to the spatial scale and their behaviour is influenced by the stability or changes of river environmental conditions (Schneider et al., 2012). 


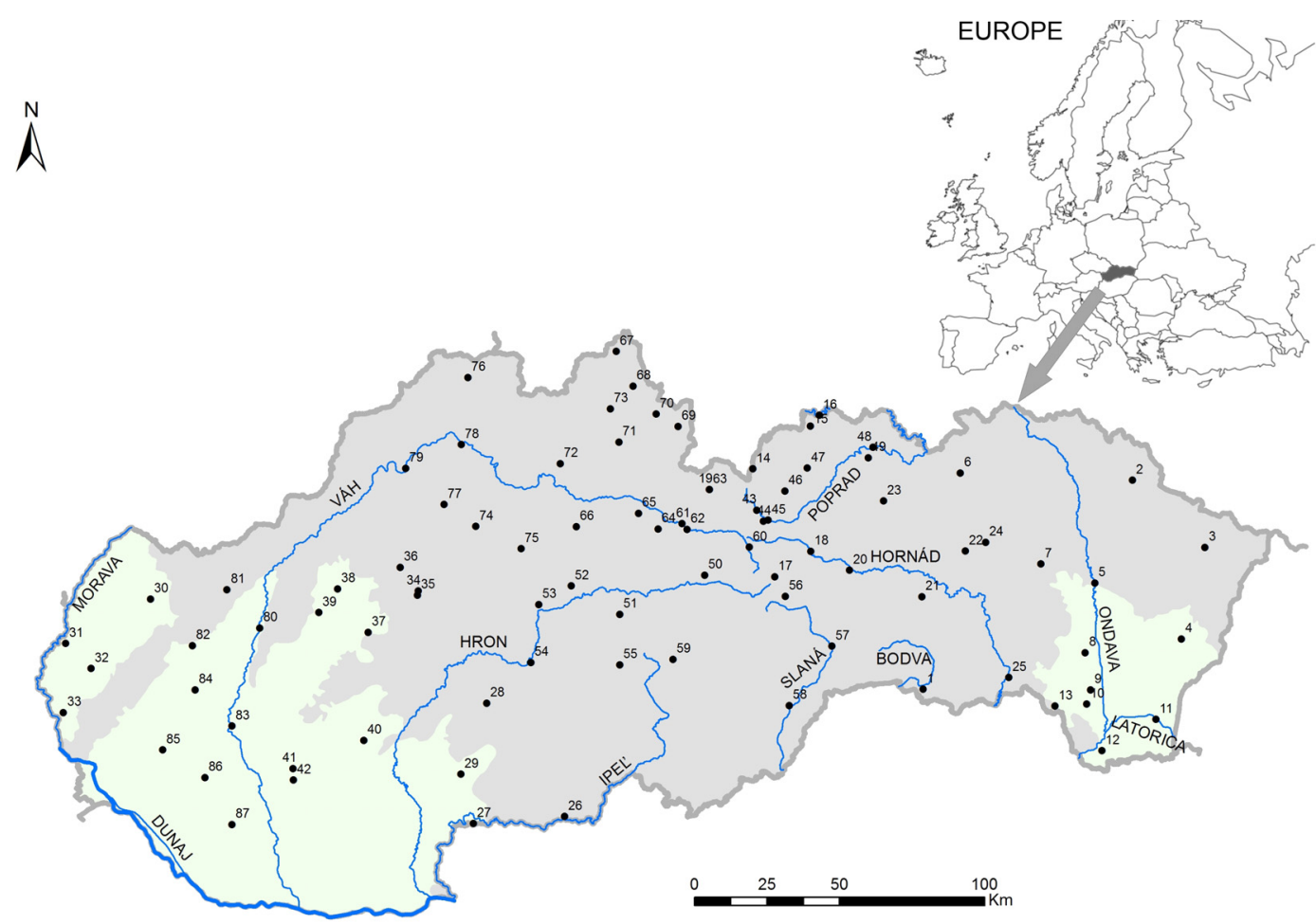

Figure 1

Distribution of the surveyed sites within two designated ecoregions in Slovakia - the Pannonian Lowland (green) and the Carpathians (grey).

Prior to the implementation of WFD requirements, the research of macrophytes in running waters in Slovakia was primarily focused on vascular plants, while non-vascular plants such as bryophytes were studied only marginally (e.g. Hrivnák et al., 2003, 2007; Ot'ahel'ová et al., $2007 a, 2007 b)$. More systematic research of bryophytes and especially macro-algal growths in rivers of Slovakia started within the monitoring aimed at the assessment of ecological status in the recent period (e.g. Baláži and Tóthová, 2010a,2010b; Baláži et al., 2010,2011; Hrivnák et al., 2010).

In connection with the existence of many new data about bryophytes and macro-algal growths obtained from the river macrophyte monitoring in Slovakia, the following objectives were suggested: (i) to describe the structure of macrophytes focusing especially on bryophytes and macro-algal growths, (ii) to detect the influence of the studied environmental variables on the species composition, (iii) to describe the importance of macrophytes (bryophytes and macro-algal growths) in ecological assessment.

\section{MATERIALS AND METHODS}

\section{> STUDY AREA}

Surveys of aquatic plant communities were carried out at representative sites in designated water bodies within the Framework Monitoring Programme of Slovakia among others focused on the assessment of ecological status. Out of all sites surveyed in the years 2010-2013, 87 sites (73 rivers) evenly distributed throughout the country were selected for further analyses based on the presence of bryophytes or macro-algal growths at the surveyed sites (Figure 1, Appendix I).

According to the Water Plan of the Slovak Republic (Ministry of Environment of the Slovak Republic, 2011), two river basin districts are designated at the national level in Slovakia, namely the Danube River Basin District (96\% of the SR territory) and the Vistula River Basin 


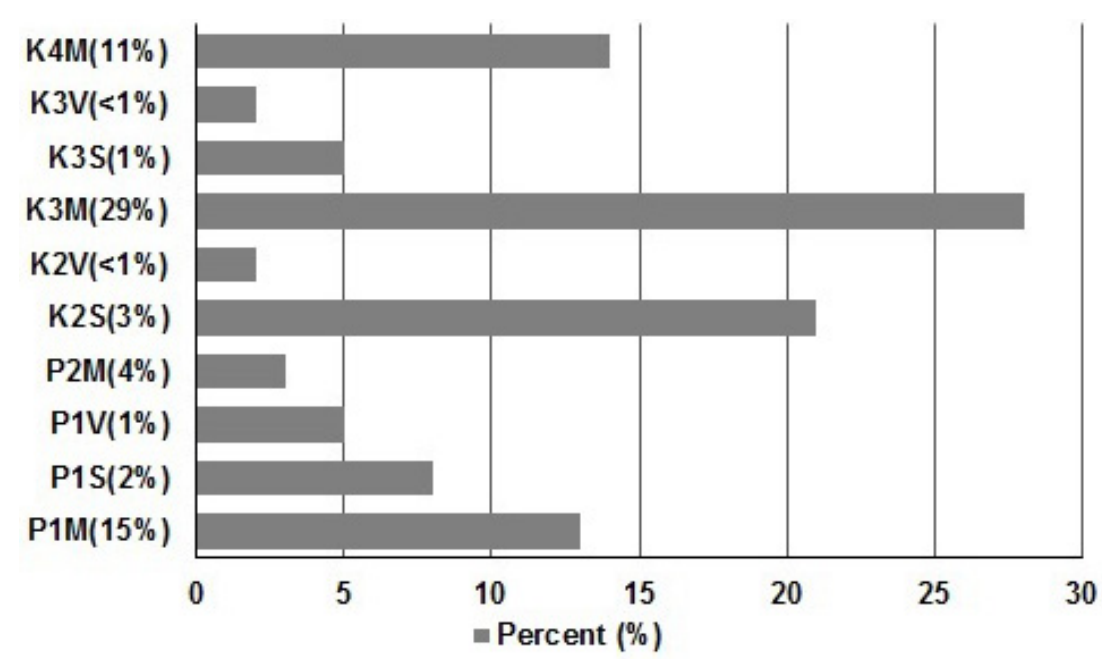

\section{Figure 2}

Percentage of survey sites within selected water body types in Slovakia. Ecoregions : K - the Carpathians, $P$ - the Pannonian Lowland; altitude typology : 1 - lowland ( $<200 \mathrm{~m}$ a.s.l.), 2 - mid-altitude (200 to $500 \mathrm{~m}$ a.s.l.), 3 - high (501 to $800 \mathrm{~m}$ a.s.l.), 4 - very high (>800 $\mathrm{m}$ a.s.l.); size typology based on catchment area: $M$ - small (10 to $\left.100 \mathrm{~km}^{2}\right), \mathrm{S}$ - medium (101 to $\left.1000 \mathrm{~km}^{2}\right), \mathrm{V}$ - large $\left(>1000 \mathrm{~km}^{2}\right.$ ). Percentage of all water bodies within selected water body types in Slovakia is mentioned in the parenthesis following the water body type at the $y$-axis.

District (4\% of the SR territory). All water courses with catchment area above $10 \mathrm{~km}^{2}$ were the subject of typology. Individual surface water types were determined on the basis of abiotic descriptors determined under the system A of Annex II WFD, as follows: ecoregion, altitude and size (catchment area) typology and geological composition. Slovakia belongs to two ecoregions: the Carpathians ( $72 \%$ of the SR territory) and the Pannonian Lowland ( $28 \%$ of the SR territory), which is a part of the Hungarian Lowland ecoregion. According to altitude, and catchment area, four and three categories are defined, respectively. Geological composition is defined as "mixed type" at present, therefore it does not de facto act as a water course typology descriptor. Totally, eighty-seven selected sites are distributed in all sub-basins of both River Basin Districts. They represent all water body types in Slovakia (Figure 2) except the type K2M. This type represents small Carpathian rivers located at the altitude of 201 to $500 \mathrm{~m}$ a.s.l. Because of the absence of aquatic macrophytes, this type was excluded from monitoring aimed at the assessment of ecological status based on macrophytes.

The majority of sites $(72 \%)$ were a part of the Carpathians, while the rest was situated in the Pannonian Lowland. Most sites belonged to the water body type K3M (small mountain rivers with an altitude from 501 to $800 \mathrm{~m}$ a.s.I.), followed by sites from the types K2S, K4M. Altogether, more than $60 \%$ of all survey sites were located in these three water body types. In the Pannonian Lowland the largest number of sites was a part of the water body type P1M representing small rivers with an altitude less than $200 \mathrm{~m}$ a.s.l. However, the highest number of surveyed sites was situated in small rivers (60\%) in contrast to large rivers (less than $10 \%)$.

\section{> SAMPLING PROCEDURE}

Macrophyte surveys were conducted using the general principles described in the European Standard EN 14184:2014. Monitoring was performed at representative sites of the designated water bodies for the purpose of assessing the ecological status. Field surveys were carried out in the summer between July and early September in the years 2010-2013. The length of the survey stretch at representative sites was selected to ensure that the total species spectrum was included. On average $100 \mathrm{~m}$ long stretch was surveyed. If no new species occurred within the last $25 \mathrm{~m}$ of the survey stretch, the survey was finished after $100 \mathrm{~m}$. If constantly new species were found, the stretch was extended by further $25 \mathrm{~m}$ until no further species occurred. As a result of this procedure, in the case of small and medium-sized rivers, 
survey reached usually a length of $100 \mathrm{~m}$. In contrast, in the case of large rivers, survey stretches reached a length of up to $500 \mathrm{~m}$. Field survey was performed by wading upstream in a zigzag manner across the river bed. In the case of large rivers (depth $>1.5 \mathrm{~m}$ ), a boat was used.

In each surveyed stretch the Plant Mass Estimate (PME) was evaluated using a five-level scale based on the occurrence and percentage cover respectively: 1 (rare; only single plants, up to about 5 specimens), 2 (occasional; about 6 to 10 specimens), 3 (frequent; up to 10\%), 4 (abundant; from 11 to $50 \%$ ) and 5 (very abundant; more than $50 \%$ ). Macrophyte surveys included the identification of three taxonomic groups; macro-algal growths, bryophytes and vascular plants. The determination of taxa focused primarily on indicators of the Macrophyte Biological Index for Rivers (IBMR; Haury et al., 2006). Therefore, the determination of macro-algal growths was mostly performed at the genus level, while the other taxonomic groups were determined at the species level. The nomenclature of non-vascular and vascular plants followed Marhold and Hindák (1998). Moreover, the proportions of various growth forms of plants were assessed distinguishing three categories: helophytes (emergent plants), hydrophytes (true aquatic plants including submerged plants, pleustophytes and floating leaf-rooted plants) and amphiphytes (occurring in two growth forms in studied areas, helophytes and hydrophytes; c.f. Janauer, 2003; Janauer and Dokulil, 2006).

\section{> ENVIRONMENTAL VARIABLES}

The following environmental variables were measured monthly from January to December in water at each representative site during the monitoring years: dissolved oxygen $\left(\mathrm{O}_{2}\right)$, biochemical oxygen demand (BOD), chemical oxygen demand (COD), $\mathrm{pH}(\mathrm{pH})$, temperature $(t)$, electrical conductivity $(\mathrm{CON})$, ammonia nitrogen $\left(\mathrm{NH}_{4}-\mathrm{N}\right)$, nitrate nitrogen $\left(\mathrm{NO}_{3}-\mathrm{N}\right)$, total nitrogen (TN), total phosphorus (TP), orthophosphate phosphorus $\left(\mathrm{PO}_{4}-\mathrm{P}\right)$ and alkalinity (KNK 4.5). The given chemical variables were sampled in free water and taken from the surface. Some variables such as oxygen, temperature, $\mathrm{pH}$ and electrical conductivity were measured directly in situ using a WTW MULTI 340i portable device. Laboratory analyses were carried out by the staff of the Slovak Water Management Enterprise according to methods included in ISO and EN standards mentioned in Baláži et al. (2014). Annual averages of chemical variables were subsequently used for statistical analyses.

In the group of environmental variables, altitude and also data of land use type processed by the CORINE Land Cover (European Environmental Agency, 2000) were used. The first level (5 classes) of the CORINE Land COVER was used, which corresponds to the main categories of land cover (artificial areas, agricultural land, forests and semi-natural areas, wetlands and water surfaces).

\section{> STATISTICAL ANALYSES AND CALCULATIONS}

Macrophytes: Coefficients of frequency $(F)$ and dominancy $(D)$ were calculated for a description of the macrophyte assemblages. The coefficient of frequency $(F)$ was calculated by formula:

$$
F=\sum A_{i-n} / B \times 100
$$

where $A_{i}$ is the number of surveys in which the species occurred and $B$ is the total number of surveys.

The coefficient of dominancy $(D)$ was calculated using the following formula:

$$
D=\sum X_{i-n} / Y \times 100
$$

where $X_{i}$ is the sum of all PME values of certain taxa in all surveys and $Y$ is the sum of all PME values of all taxa in all surveys. 
Environmental variables: At the first step, only one characteristic was selected from the pair of strongly correlated environmental variables using Pearson correlations except land-use types. Therefore, only 12 variables $\left(\mathrm{O}_{2}, \mathrm{BOD}, \mathrm{pH}, \mathrm{CON}, \mathrm{NH}_{4}-\mathrm{N}, \mathrm{TP}\right.$ as physicochemical variables and altitude, artificial areas, agricultural land, forests and semi-natural areas, wetlands and water surfaces as landscape and geographical variables) were used for further statistical analyses. Some variables, which did not follow normal distribution (Shapiro-Wilk test), were logarithmically or arcsin transformed to approximate a normal distribution (Table I).

Ordination methods were used to detect effects of the studied environmental variables on the species composition of macrophyte assemblage. The length of the gradient in Detrended Correspondence Analysis (DCA) was 4.36, showing that unimodal methods were more appropriate for further analysis. Only presence/absence species data were used for both DCA and Canonical Correspondence Analysis (CCA); rare species were down-weighted. The CCA was performed to investigate (i) simple term effects (independent effects of all explanatory variables) and (ii) conditional term effects (partial effects of each predictor). Interactive stepwise (forward) selection was used and the significance of environmental variables was tested by the Monte Carlo permutation test with 999 unrestricted permutations (ter Braak and Šmilauer, 2012). P-values were adjusted by the "false directory rate" (ter Braak and Šmilauer, 2012). Conditional effects of the two mentioned groups of variables, (i) physicochemical and (ii) landscape and geographical ones, were used in variation partitioning. CANOCO 5.0 for Windows package was used for all analyses (ter Braak and Šmilauer, 2012).

Pearson correlation coefficients were calculated among environmental variables. Spearman correlations were used to identify the relationship between environmental variables and the position of samples on the first two ordination axes in DCA. In both cases, the STATISTICA software was used (StatSoft Inc., 2011).

For ecological evaluation, the IBMR (Haury et al., 2006) was used, which was included in the Slovak national method for the assessment of ecological status based on macrophytes (NV SR 269/2010 Z. z.). IBMR species values range from 0 to 20; 0 indicating hypertrophic and 20 indicating oligotrophic conditions, respectively. Each taxon is allocated a taxon score $(0-20)$ according to its response to eutrophication and a coefficient of ecological amplitude (1-3); 1 representing wide amplitude and 3 representing a very limited amplitude. The IBMR was calculated according to NF T90-395:2003. Indicator taxa list was modified reflecting the conditions in Slovakia (Baláži and Tóthová, 2010b). Some species (e.g., Porella pinnata L., Fissidens polyphyllus Wilson ex Bruch \& Schimp., Fontinalis duriaei Schimp., Hyocomium armoricum (Brid.) Wijk \& Marg., Octodiceras fontanum (La Pyl.) Lindb., Orthotrichum rivulare Turner, Pachyfissidens grandifrons (Brid.) Limpr.), which have never been found in Slovakia, were excluded from the original indicator taxa list, and domestic species not present in IBMR (Hygrohypnum styriacum (Limpr.) Broth, Porella cordaeana (Huebener) Moore) were included. These last-mentioned species were allocated the following values of taxon score and a coefficient of ecological amplitude: $H$. styriacum: 19/3; P. cordaeana: 15/2. Filamentous bacteria were excluded from indicator taxa list, because they had already been included in the Slovak method for the assessment of ecological status based on phytobenthos.

With the aim to find out the contribution of selected groups (bryophytes and macro-algal growths) to the mean IBMR value determined for each water body type, the simulated mean IBMR value (without vascular plants) was calculated.

Within the subsequent analyses, particular taxa of bryophytes and macro-algal growths were identified, which exhibited an important contribution to the mean IBMR value based on taxa score comparison.

\section{RESULTS}

\section{> STRUCTURE OF MACROPHYTE ASSEMBLAGES}

At 87 sites included in the study, 62 taxa of macrophytes were determined: 28 vascular plants, 13 mosses, 5 liverworts and 16 macro-algal growths. Hydrophytes represented $79 \%$ of all 


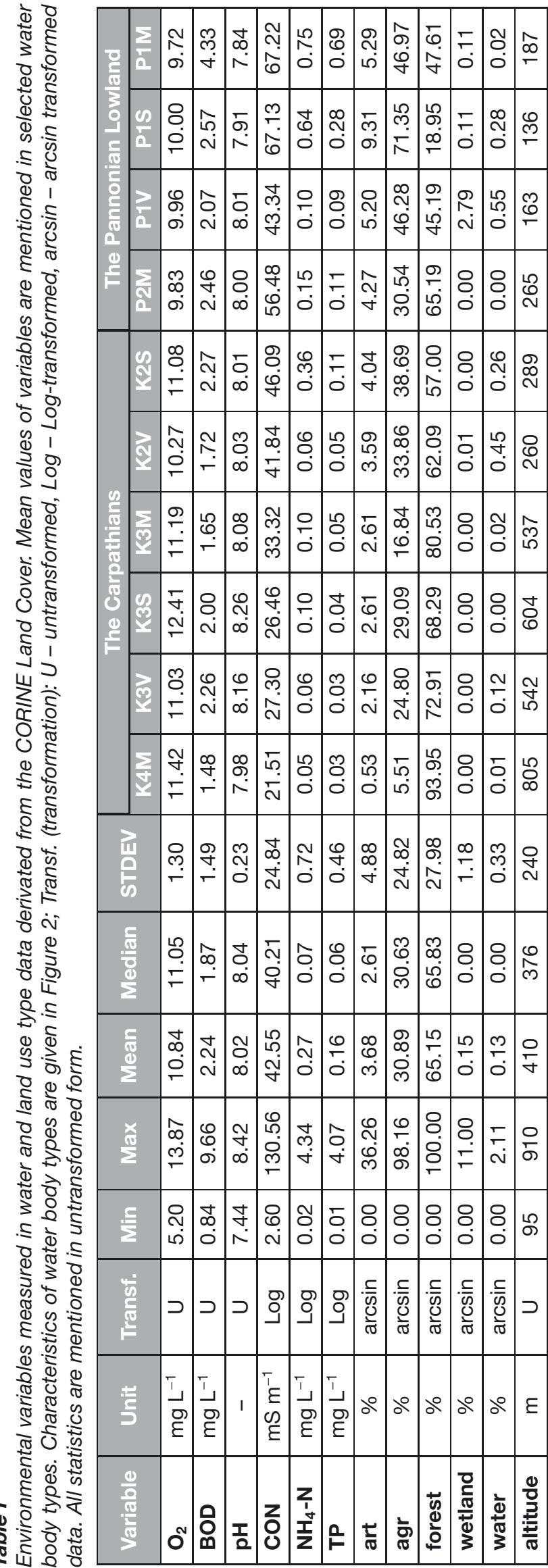




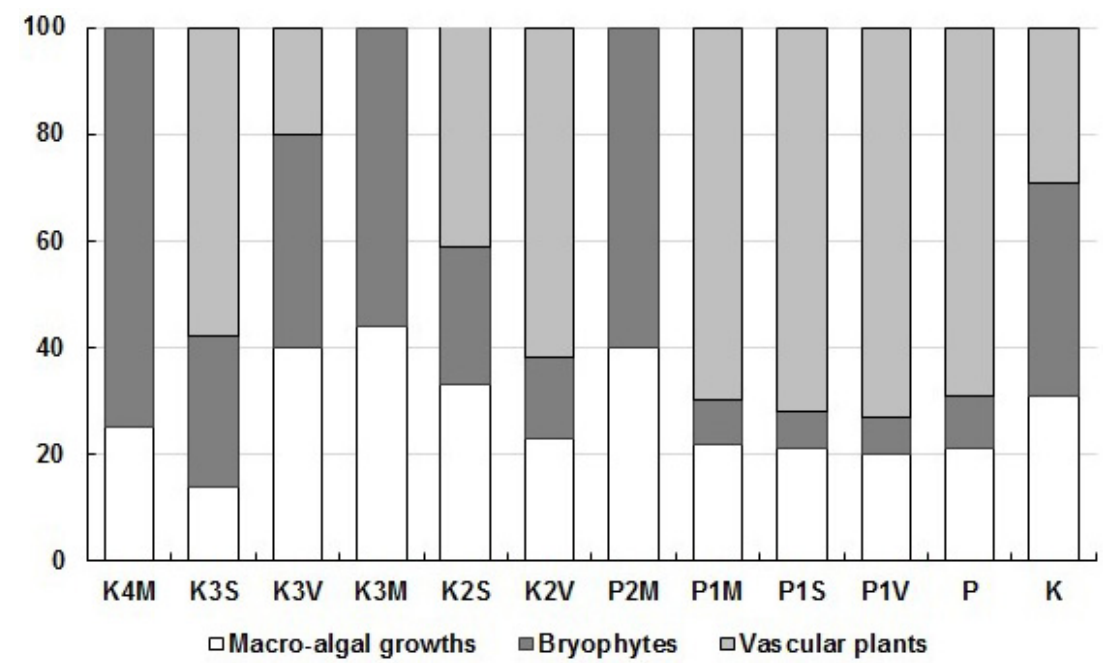

\section{Figure 3}

Percentage of macrophytes within three taxonomic groups in selected water body types. $P$ - the Pannonian Lowland, $K$ - the Carpathians. Characteristics of particular water body types (K4M, K3S, K3V, $K 3 M, K 2 S, K 2 V, P 2 M, P 1 M, P 1 S, P 1 V)$ are given in Figure 2.

macrophytes, the rest (21\%) was represented by amphiphytes (Appendix II). Considerable differences were found within taxonomic groups between both ecoregions (Figure 3). In the Carpathian ecoregion, the representation of macrophytes increased from vascular plants over macro-algal growths to bryophytes, while in the Pannonian Lowland, it was in the opposite order. Cladophora sp. reached the highest coefficient of frequency and dominancy. Brachythecium rivulare, Fontinalis antipyretica and Rhynchostegium riparioides were frequent $(F>25 \%)$ and dominant $(D>5 \%)$.

Vascular plants occurred rarely; no species with $F>20 \%$ were noted.

\section{> STRUCTURE OF BRYOPHYTES AND MACRO-ALGAL GROWTHS}

Based on a previous selection focused on the occurrence of bryophytes and macro-algal growths at survey sites, the results indicate that they occurred frequently in water body types K3M, K2S, K4M, P1M, P1S (Figure 2).

Bryophytes occurred mainly in the Carpathians, where they represented the dominant community. They were found mainly in two types K3M and K4M representing more than $40 \%$ of all water bodies in Slovakia. On the contrary, their occurrence in the Pannonian Lowland was rare. However, because of the absence of vascular plants they were dominant also in the water body type P2M. Brachythecium rivulare, Fontinalis antipyretica, Rhynchostegium riparioides and Amblystegium tenax occurred most frequently.

The occurrence of macro-algal growths was relatively balanced in both ecoregions. In mountain small streams (K3M, K4M) the species such as Cladophora sp., Hildenbrandia rivularis, Hydrurus foetidus and Phormidium sp. were common, while in lowland rivers Cladophora sp., Oedogonium sp. and Oscillatoria sp. occurred frequently (Appendix II).

\section{> ENVIRONMENTAL CHARACTERISTICS}

Basic characteristics of the measured environmental variables are shown in Table I and Appendix I. In the Pannonian Lowland ecoregion, the nutrient load, BOD, CON, percentage of agricultural land and artificial surfaces were the highest, while in the Carpathians, the values of $\mathrm{O}_{2}$ and percentage of forest and semi-natural areas were the highest. In the view of the above mentioned trends, the lowest value of $\mathrm{O}_{2}\left(5.20 \mathrm{mg} \mathrm{L}^{-1}\right)$ and the highest values of BOD (9.66 mg L ${ }^{-1}$ ), CON (130.56 mS m${ }^{-1}$ ) and nutrients (NH4-N: $4.34 \mathrm{mg} \mathrm{L}^{-1}$; TP: $4.07 \mathrm{mg} \mathrm{L}^{-1}$ ) 

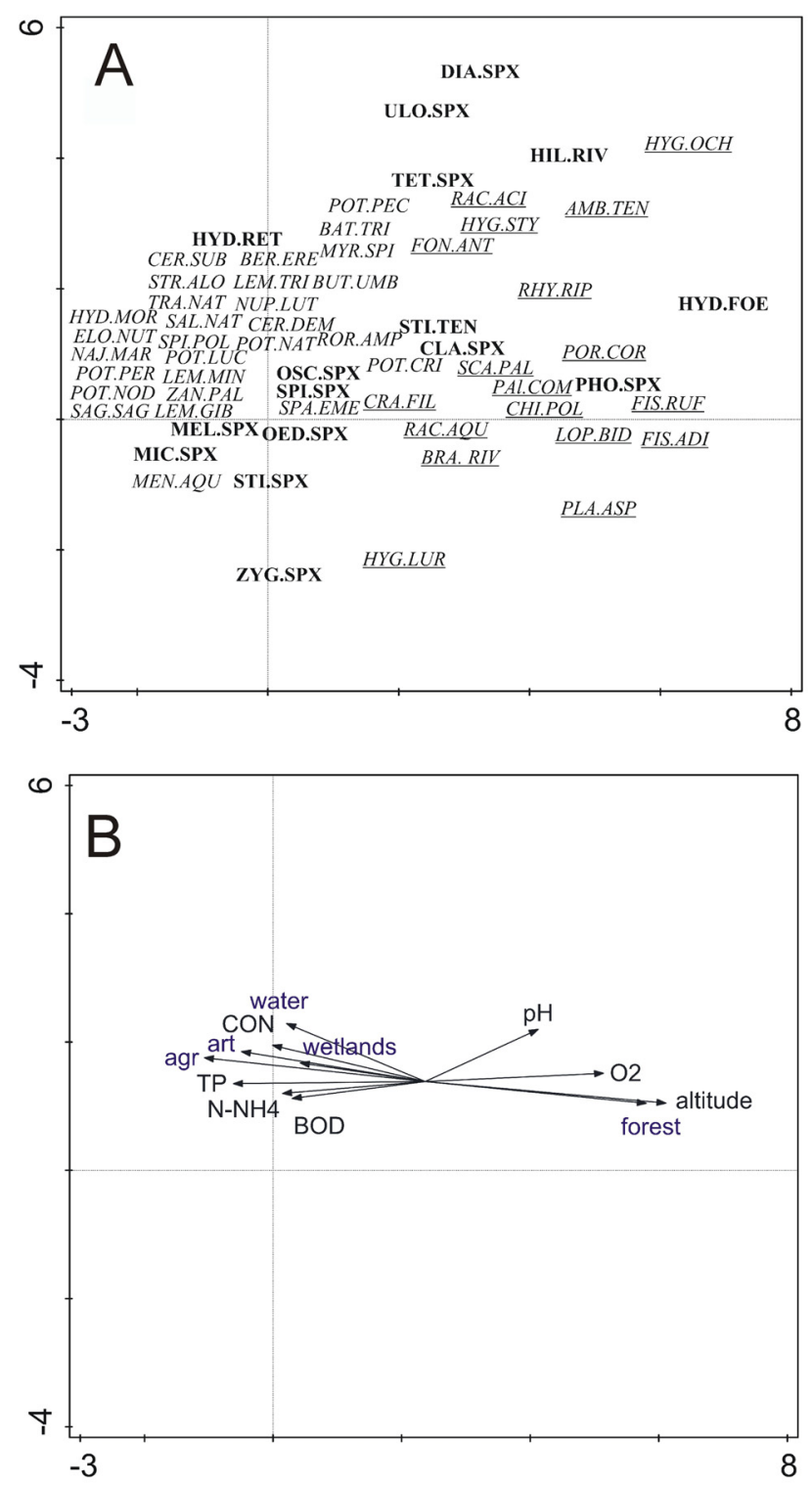

\section{Figure 4}

$D C A$ ordination diagram with species $(A)$ and explanatory variables $(B)$. Bold-printed taxa represent macro-algal growths, underlined bryophytes and regular font vascular plants. Abbreviations of species are presented in Appendix II and environmental variables in Table II; land use types are displayed blue.

were found in sites included in the Pannonian Lowland. The water $\mathrm{pH}$ gradient at survey sites was relatively narrow, ranging from 7.44 to 8.42 .

\section{> MACROPHYTE COMPOSITION-ENVIRONMENTAL VARIABLE RELATIONSHIPS}

The position of macro-algal growths was relatively uniformly distributed over the ordination space, while the position of vascular plants and bryophytes was concentrated on the opposite margins (Figure 4A). All studied environmental variables had a statistically significant $(p<$ 0.01 ) effect on the species composition of macrophytes (Figure 4B). Altitude (Spearman's $r=$ 0.91 ), forests and semi-natural areas $(0.81)$, agricultural areas $(-0.80)$ and total phosphorus $(-0.73)$ had the highest correlations with the first DCA axis. The presence of bryophytes was 


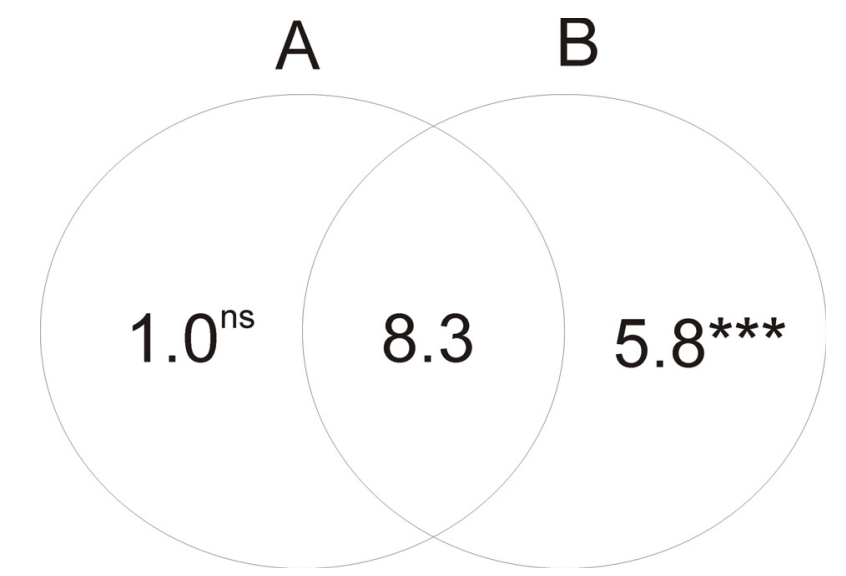

\section{Figure 5}

Variation partitioning of environmental variables statistically significant in conditional term effects (CCA). A, $B$ - see Table II.

positively associated with altitude and the presence of forests and semi-natural areas in the landscape and negatively with agricultural areas, while in the case of vascular plants, the influences were opposite (Figure 4B).

Simple effects (CCA) of the studied variables explained $27.0 \%$ of the total variation (adjusted explained variation is $15.1 \%$ ) and effects for all variables were statistically significant. On the contrary, only two variables, altitude and water surfaces had significant effects on the macrophyte composition when the stepwise (forward) selection was used and they explained $13.7 \%(11.6 \%)$ of the variability (Table II).

Variation partitioning showed that the shares of environmental variables on the total variation decreased in the following order: both groups together $(A+B)$, followed by landscape and geographical variables (group $B$ ) and purely physicochemical variables (group $A$ ) which had an insignificant effect on macrophyte composition (Figure 5).

\section{> MACRO-ALGAL GROWTHS AND BRYOPHYTES AS A PART OF MACROPHYTES USED FOR ECOLOGICAL ASSESSMENT}

Out of the 62 taxa determined, only five taxa (Fissidens adianthoides, Lophocolea bidentata, Plagiochila asplenioides, Racomitrium aquaticum and Salvinia natans) were not included among indicators of IBMR. The IBMR values varied from 4.92 to 15.80 with mean value (10.44; Table III).

Because of the absence of vascular plants, IBMR values were represented by bryophytes and macro-algal growths exclusively in the following 3 water body types K4M, K3M, P2M. The highest mean IBMR value (13.51) was found in the type $\mathrm{K} 4 \mathrm{M}$, representing small mountain streams. The mean IBMR values among particular water body types decreased in the following order: $\mathrm{K} 4 \mathrm{M}, \mathrm{K} 3 \mathrm{M}, \mathrm{K} 3 \mathrm{~V}, \mathrm{P} 2 \mathrm{M}, \mathrm{K} 2 \mathrm{~S}, \mathrm{~K} 2 \mathrm{~V}, \mathrm{~K} 3 \mathrm{~S}, \mathrm{P} 1 \mathrm{M}, \mathrm{P} 1 \mathrm{~V}$ and $\mathrm{P} 1 \mathrm{~S}$, more or less in accordance with decreasing altitude. The lowest mean IBMR value (7.21) was observed in the water body type P1S, representing medium-sized lowland rivers.

Simulated mean IBMR values were lower than the original (real) IBMR values in the following 4 types: K3V, K3S, K2V, P1M, while in 2 types (P1V and P1S) they were higher.

\section{DISCUSSION}

Based on ordination analyses, our results showed an obvious shift between mountain and lowland river types from vascular aquatic plants to aquatic bryophytes, while macro-algal growths were relatively uniformly distributed in the whole ordination space. All evaluated environmental variables strongly corresponded with this pattern. However, altitude and water surfaces as a land use type were the main environmental factors responsible for this pattern. Studies from running waters proved that bryophyte occurrence corresponds to altitude, 


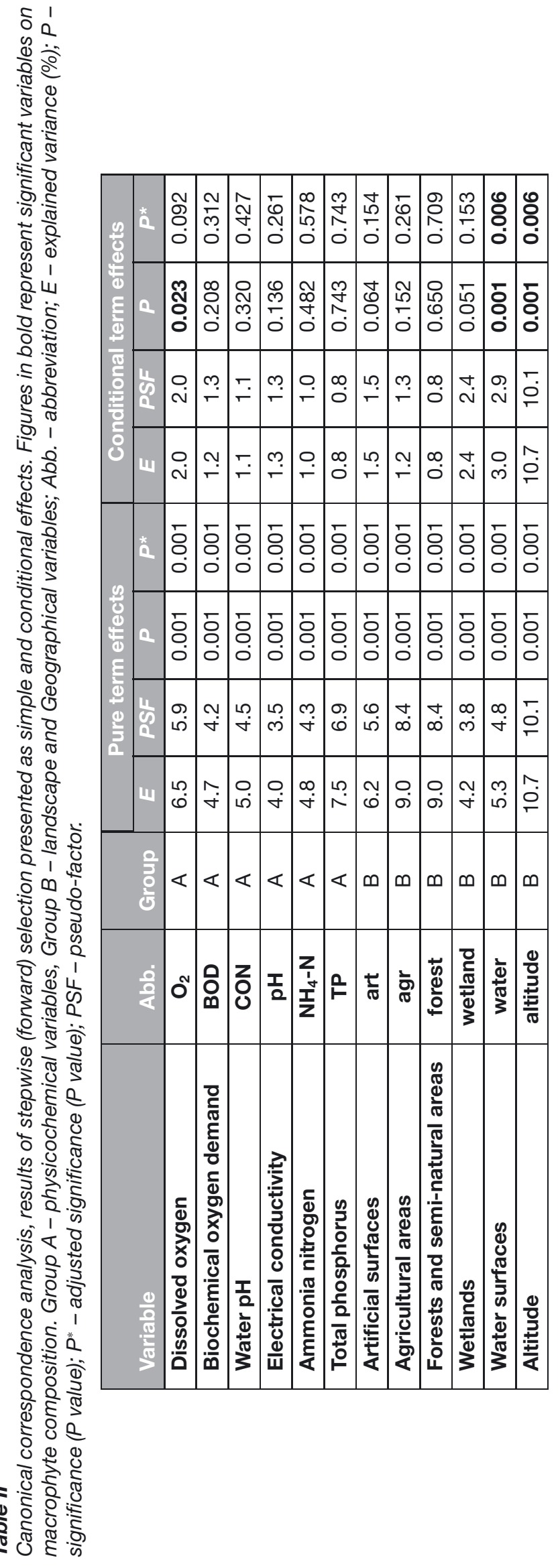




\section{Table III}

The Macrophyte Biological Index for Rivers (IBMR) in selected water body types. Figures in bold represent the samples comprising bryophytes and macro-algal growths exclusively, Mean - the real (original) mean IBMR value/*Mean - the simulated mean IBMR value (without vascular plants).

\begin{tabular}{|c|c|c|c|c|c|c|}
\hline \multirow{2}{*}{ Water body types } & \multirow{2}{*}{ Number of sites } & \multicolumn{4}{|c|}{ IBMR } & \multirow{2}{*}{$\begin{array}{l}\text { Number } \\
\text { of taxe }\end{array}$} \\
\hline & & Mean / *Mean & Min & Max & STDEV & \\
\hline K4M & 12 & $13.51 / 13.51$ & 10.67 & 15.80 & 1.64 & 22 \\
\hline K3V & 2 & $10.53 / 10.36$ & 9.69 & 11.38 & 1.19 & 5 \\
\hline K3S & 4 & $9.15 / 9.10$ & 7.67 & 10.22 & 1.13 & 7 \\
\hline K3M & 24 & $12.01 / 12.01$ & 8.00 & 15.78 & 1.69 & 18 \\
\hline K2V & 2 & $9.48 / 8.86$ & 8.34 & 10.63 & 1.62 & 13 \\
\hline K2S & 18 & $9.57 / 9.57$ & 6.97 & 14.65 & 1.66 & 25 \\
\hline P2M & 3 & $10.11 / 10.11$ & 9.14 & 12.00 & 1.63 & 5 \\
\hline P1V & 4 & $7.72 / 9.63$ & 7.24 & 8.36 & 0.48 & 15 \\
\hline P1S & 7 & $7.21 / 8.21$ & 4.92 & 9.94 & 1.58 & 28 \\
\hline P1M & 11 & $8.86 / 7.65$ & 7.28 & 10.47 & 1.13 & 24 \\
\hline $\begin{array}{l}\text { The Pannonian } \\
\text { Lowland } \\
\end{array}$ & 25 & $8.37 / 9.30$ & 4.92 & 12.00 & 1.54 & 39 \\
\hline The Carpathians & 62 & $11.28 / 10.57$ & 6.97 & 15.80 & 2.22 & 45 \\
\hline All types & 87 & $10.44 / 10.06$ & 4.92 & 15.80 & 2.43 & 62 \\
\hline
\end{tabular}

water velocity, clearness, substratum size, shading shrubs and trees on the banks and the quality of water physico-chemical status (Ceschin et al., 2012; Hrivnák et al., 2010; Luis et al., 2015). On the contrary, the presence of aquatic vascular plants is typical of medium to broadsized, slowly running lowland eutrophic open waters with a fine substratum on the bottom (Haslam, 2006). Similar findings are evident in case of our study. Macro-algal growths represent probably a more heterogenous group than aquatic vascular plants or bryophytes with occurrence on the whole scale of the studied aquatic habitats (cf. Janauer and Dokulil, 2006).

Altitude is a surrogate variable for climatic factors such as a temperature or precipitation, and along this gradient, macrophyte richness decreases and species composition of aquatic plants is changed (Lacoul and Freedman, 2006). Besides two land use types (water surfaces and wetlands) and water reaction, altitude correlated with all other environmental variables in our study. Altitude thus represents the gradient from relatively clear and oxygen-saturated running waters within forested mountainous landscape to eutrophic and human-affected lowland rivers. Water surfaces represented non-correlated landscape factor with a strong influence on the macrophyte composition. They represent a landscape type which occurs along the whole altitudinal gradient and which can be a source of additional species for rivers in association with, for instance, their common hydrological connectivity (Ward et al., 2002). Results of variation partitioning showed that landscape and geographical variables and their overlap with physicochemical variables had the highest effect on species composition. This pattern is not surprising; a strong effect of landscape and geographical variables on species composition in comparison with physicochemical variables is known from aquatic habitats in Slovakia and other European countries (Hrivnák et al., 2013, Manolaki and Papastergiadou, 2015). However, the influence of physicochemical characteristics can play an important role in species composition pattern (Dodkins et al., 2005; Ferreira and Moreira, 1999; Szoszkiewicz et al., 2014).

Due to their indication features, bryophytes and macro-algal growths in rivers represent important taxonomic groups for ecological assessment. Both are a part of various metrics, e.g., MTR (Dawson et al., 1999) or IBMR (Haury et al., 2006), used for the assessment of ecological status. The given groups are particularly important in small mountain streams, where they are almost exclusively attached to a wide variety of substrates and form dominant communities within macrophytes. Based on our results, macrophytes were represented exclusively by bryophytes and macro-algal growths in small mountain streams. Namely, bryophytes Ambylstegium tenax, Brachythecium rivulare, Rhynchostegium riparioides and macro-algal growths 
Cladophora sp., Hildenbrandia rivularis, Hydrurus foetidus and Phormidium sp. have been frequent there. Janauer and Dokulil (2006) mentioned that in springs only a few species (stoneworts and bryophytes) are present due to limited nutrient load and fast water flow. In contrast, in middle and lower reaches, where water flow is slow and the width of water course prevents heavy shading, macrophytes (vascular plants) become abundant. The mentioned pattern is generally known from European streams, where there is an obvious shift from the predominance of species-poor, moss- and liverwort-dominated communities in small-sized, shallow mountain streams to more rich communities dominated by vascular plants in medium-sized, lowland rivers (Baattrup-Pedersen et al., 2006). Due to a number of surveyed sites and taxa of bryophytes and macro-algal growths, especially medium-sized upland rivers (K2S) seem to be as an intermediate step between small mountain streams and lowland rivers. A diverse macrophyte community is developed there by vascular plants with a significant share of bryophytes and macro-algal growths probably because of the presence of stretches with fast water flow, hard substratum on one hand and higher conductivity and nutrient loads on the other hand. Moreover, within mean IBMR values comparison (original/real and simulated IBMR values), bryophytes and macro-algal groups had no important contribution on the mean IBMR value in medium-sized upland rivers.

Within the Carpathian ecoregion, especially Cladophora sp., followed by Hydrodictyon reticulatum and Fontinalis antipyretica had a substantial contribution to mean IBMR values in large upland rivers (K2V, K3V). They reduced the mean IBMR values.

In addition, Cladophora sp. was the most abundant species and occurred frequently in both ecoregions (the Carpathians and the Pannonian Lowland) and in all selected water body types. Dodds and Gudder (1992) stated that Cladophora sp. may be the most ubiquitous macroalga in fresh-waters worldwide. Szoszkiewicz et al. $(2010,2014)$ also mentioned that Cladophora sp. was the most common taxon in rivers among all filamentous algae. Moreover, Papastergiadou et al. (2015) mentioned that Cladophora sp. was frequent in small medium Mediterranean mountainous river type as well.

Compared to the Carpathians, bryophytes and macro-algal growths affected mean IBMR values more significantly in the Pannonian Lowland ecoregion. In medium-sized and large lowland rivers (P1S, P1V), both bryophytes Fontinalis antipyretica and Rhynchostegium riparioides and macro-algal growths Oscillatoria sp., Spirogyra sp., Microspora sp. and Stigeoclonium $\mathrm{sp}$. had an important contribution to mean IBMR values. They increased the mean IBMR values. In the case of small lowland rivers (P1M), Cladophora sp. and Oedogonium sp. were identified as taxa which decreased the mean IBMR value most markedly.

Bryophytes are included in the assessment of ecological status based on macrophytes in many European countries, e.g., Austria, Belgium, France, Germany, Great Britain, Poland (Birk and Willby, 2010), Bulgaria (Gecheva et al., 2010), Slovakia (Baláži and Tothová, 2010b) and Slovenia (Kuhar et al., 2011). Algae represent an essential part of river vegetation (Janauer and Dokulil, 2006). On the other hand, macro-algal growths are still neglected in the monitoring of rivers in many countries. Kelly (2013) gives notice that $42 \%$ from 26 states use methods for the assessment of ecological status based solely on diatoms, with no parallel assessment of nondiatom phytobenthos, even in macrophyte surveys. Our results confirmed that macro-algal growths represent a group of macrophytes which has a substantial contribution to ecological assessment in many water body types.

In conclusion, when landscape and physicochemical variables were taken into account, the first mentioned group as well as mutual interaction between mentioned groups have the most important effect on species composition of macrophytes in rivers with common occurrence of vascular and non-vascular (bryophytes and macro-algae growth) plants. Altitude had the highest influence on macrophyte composition pattern. However, due to their occurrence and indication values, bryophytes and macro-algal growths play an important role in aquatic ecosystem of running waters. Our study showed that their contribution to ecological assessment is not focused only on small mountain streams where they are dominant. Anyway, they may obviously affect ecological assessment also in many water body types in lowland rivers and large upland rivers as well. 


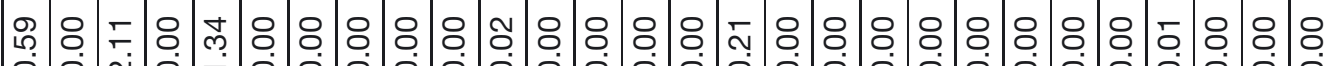

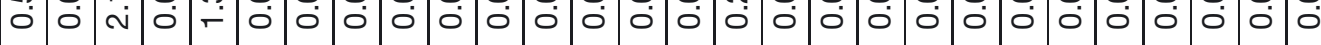

임

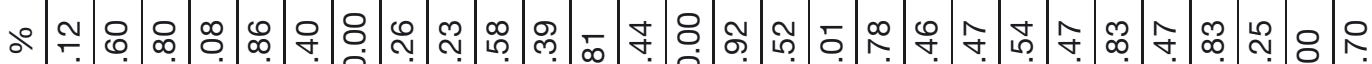

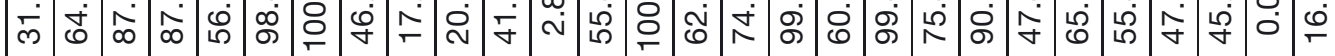

\& ঢ்

৪

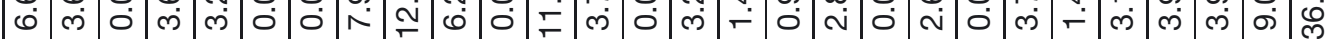

ஜ $-$ है

苗

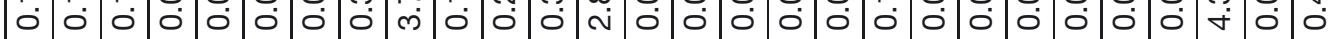

'́ ஜ

டீ

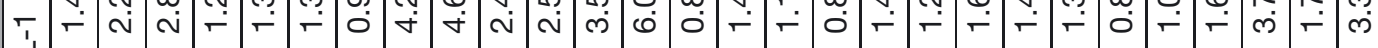

일 음을

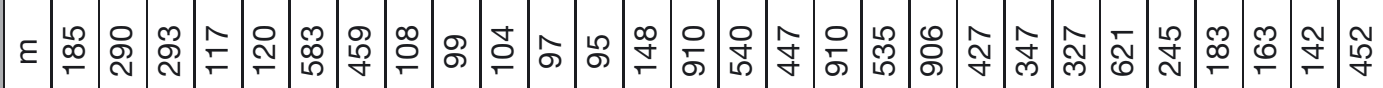

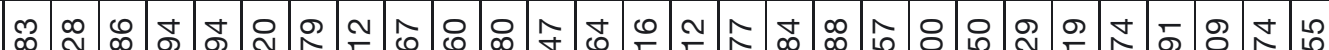

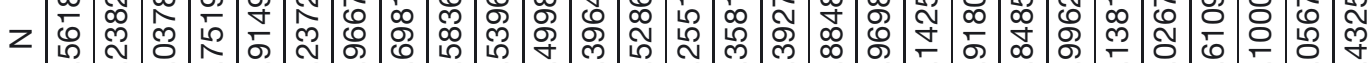

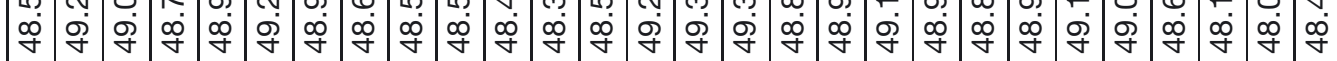

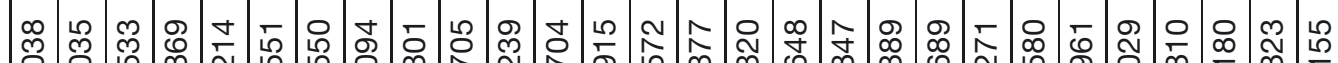
ш

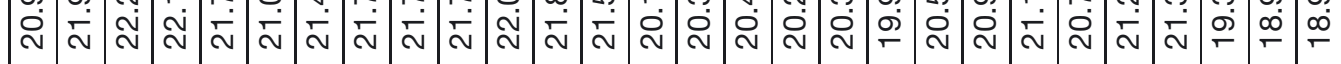

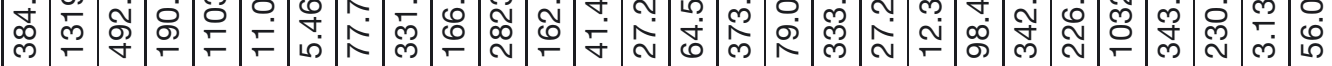

-

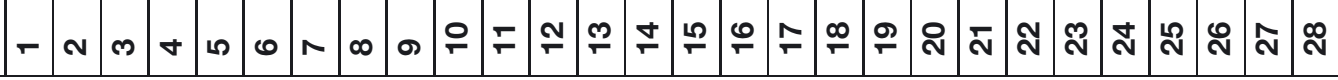




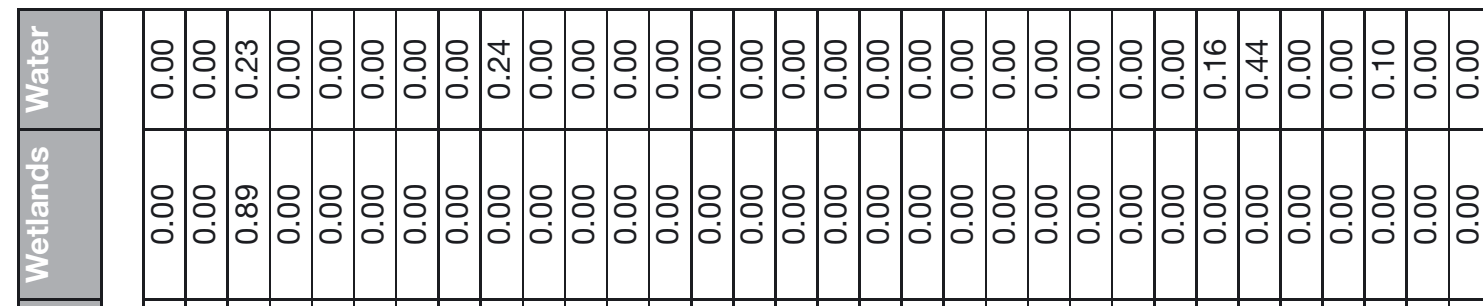

$\therefore$ ○ ம்

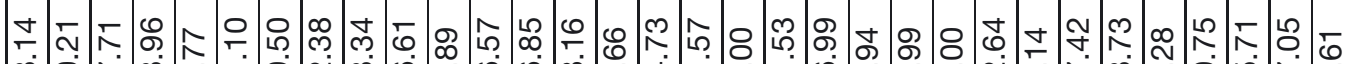
నై

\}

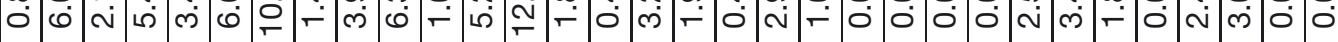

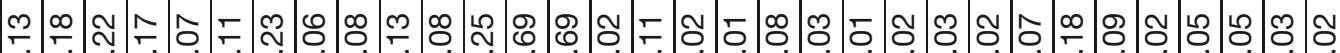

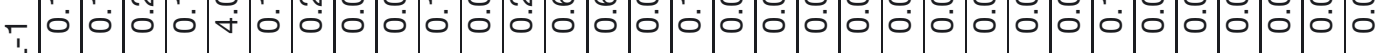

$\infty$ 등

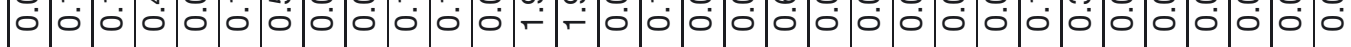

'E

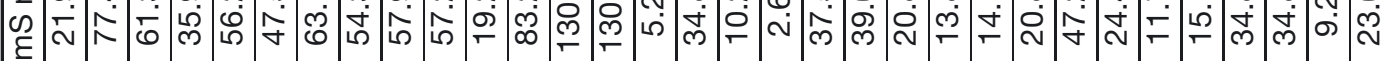

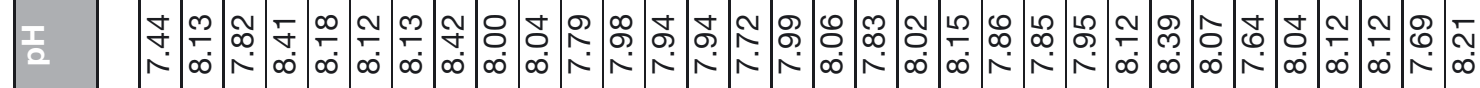

め

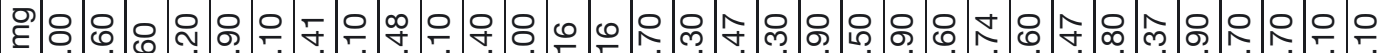

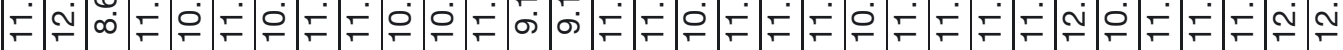

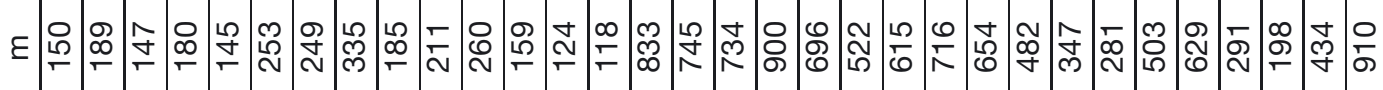

○ை

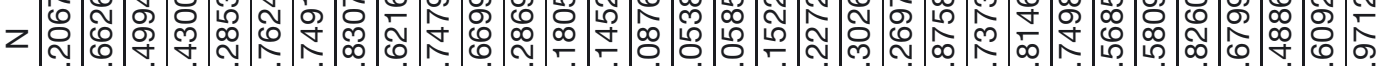
\&

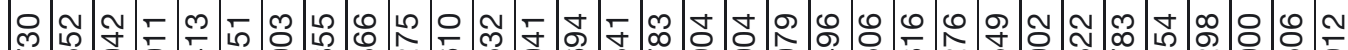

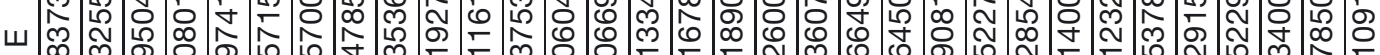

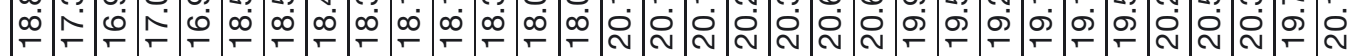




\begin{tabular}{|c|c|c|c|c|c|c|c|c|c|c|c|c|c|c|c|c|c|c|c|c|c|c|c|c|c|c|c|c|}
\hline & & & 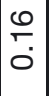 & c & ○. & $\begin{array}{l}8 \\
0 \\
0\end{array}$ & 잉 & & 잉 & 웅 & & $\mid \begin{array}{l}0 \\
0 \\
0\end{array}$ & & Oי & 우 & 우 & 우 & 우 & 우 & $\begin{array}{l}\mathscr{8} \\
\infty \\
0\end{array}$ & $\mid \begin{array}{l}\square \\
\infty \\
0\end{array}$ & \begin{tabular}{l}
8 \\
0 \\
\hdashline
\end{tabular} & $\begin{array}{l}8 \\
0 \\
0\end{array}$ & $\begin{array}{c}M \\
\infty \\
0 \\
0\end{array}$ & $\mid \begin{array}{l}0 \\
1 \\
0 \\
0\end{array}$ & 官 & $\begin{array}{l}\hat{f} \\
0\end{array}$ & 号 \\
\hline & & & $\begin{array}{l}8 \\
0 \\
0\end{array}$ & $\begin{array}{l}8 \\
0 \\
0\end{array}$ & 8: & $\begin{array}{l}8 \\
0\end{array}$ & $\begin{array}{l}8 \\
0 \\
0\end{array}$ & $\begin{array}{l}8 \\
0\end{array}$ & : & ס & Oי & Oי & Oי & Oי & $\begin{array}{l}8 \\
0 \\
\end{array}$ & $\begin{array}{l}8 \\
\\
\end{array}$ & $\begin{array}{l}8 \\
0 \\
\end{array}$ & $\begin{array}{l}8 \\
0 \\
\end{array}$ & $\begin{array}{l}8 \\
0 \\
0\end{array}$ & $\begin{array}{l}0 \\
0 \\
0\end{array}$ & $\mid \begin{array}{c}\tilde{O} \\
\delta \\
0\end{array}$ & $\begin{array}{l}8 \\
0\end{array}$ & 8 & 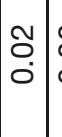 & 8 & $\overline{0}$ & $\frac{10}{10}$ & $\frac{\sim}{0}$ \\
\hline & ১ீ & $\mid \begin{array}{l}0 \\
0 \\
\dot{5} \\
\infty\end{array}$ & $\begin{array}{l}\overline{5} \\
\varnothing \\
\infty \\
\infty\end{array}$ & $\begin{array}{l}\bar{T} \\
\dot{g} \\
\dot{g}\end{array}$ & $\begin{array}{l}\text { ৪ } \\
\text { চ் }\end{array}$ & \begin{tabular}{|l}
0 \\
0 \\
$\infty$ \\
$\infty$
\end{tabular} & $\mid \begin{array}{l}\vec{T} \\
\dot{d} \\
\infty\end{array}$ & $\begin{array}{l}\stackrel{2}{0} \\
\stackrel{\leftrightarrow}{\circ}\end{array}$ & $\mid \begin{array}{c}\infty \\
\infty \\
\infty \\
\infty \\
\infty\end{array}$ & 守 & \begin{tabular}{l}
\multirow{0}{0}{} \\
$\hat{0}$
\end{tabular} & $\mid \begin{array}{l}\hat{N} \\
\dot{\sigma}\end{array}$ & $\begin{array}{l}0 \\
0 \\
0 \\
0\end{array}$ & 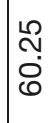 & $\begin{array}{l}\stackrel{M}{\infty} \\
\stackrel{\infty}{\infty} \\
\infty\end{array}$ & \begin{tabular}{l}
8 \\
\hdashline \\
$\dot{0}$ \\
\end{tabular} & 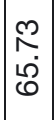 & 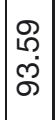 & \begin{tabular}{|l|}
$\infty$ \\
0 \\
\hdashline \\
\hdashline \\
$i n$
\end{tabular} & $\begin{array}{l}\bar{\gamma} \\
\dot{0} \\
\tilde{C}\end{array}$ & $\mid \begin{array}{l}\tilde{\delta} \\
\bar{\sigma} \\
\end{array}$ & \begin{tabular}{|l|}
$\infty$ \\
$\infty$ \\
0 \\
\\
\end{tabular} & $\mid \begin{array}{l}0 \\
\dot{q} \\
\dot{H} \\
\end{array}$ & \begin{tabular}{l|l}
$\infty$ \\
0 \\
$\infty$ \\
$\infty$ \\
$\infty$
\end{tabular} \mid & $\mid \begin{array}{l}0 \\
\mathscr{j} \\
0 \\
\infty\end{array}$ & $\mid \begin{array}{l}\infty \\
\infty \\
\infty \\
i\end{array}$ & $\begin{array}{l}\hat{N} \\
\infty \\
-\infty\end{array}$ & $\mid \begin{array}{l}\alpha \\
\tilde{j} \\
o\end{array}$ \\
\hline & & $\begin{array}{l}\mathbb{0} \\
\stackrel{+}{\leftarrow}\end{array}$ & ब. & \begin{tabular}{l}
8 \\
\hdashline \\
\hdashline
\end{tabular} & 움. & $\begin{array}{l}0 \\
0 \\
0 \\
0\end{array}$ & 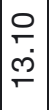 & $\begin{array}{l}\stackrel{0}{0} \\
\stackrel{\leftrightarrow}{N}\end{array}$ & \begin{tabular}{|c}
$\infty$ \\
$\infty$ \\
$\stackrel{m}{m}$ \\
\end{tabular} & $\begin{array}{l}\circ \\
\varnothing \\
\infty\end{array}$ & 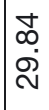 & \begin{tabular}{|l}
$\hat{\sigma}$ \\
$\dot{\sigma}$ \\
$\dot{\rho}$
\end{tabular} & 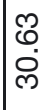 & 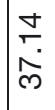 & 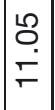 & 우 & $\begin{array}{l}\infty \\
\stackrel{\infty}{0} \\
0 \\
\infty\end{array}$ & $\begin{array}{l}\tau \\
\tau \\
0 \\
\end{array}$ & $\begin{array}{l}\bar{m} \\
\tilde{p} \\
\bar{m}\end{array}$ & 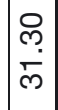 & $\mid \begin{array}{c}\hat{f} \\
\tilde{\rho} \\
\text { ले }\end{array}$ & $\begin{array}{l}\mp \\
\bar{\infty} \\
\end{array}$ & $\begin{array}{c}\bar{F} \\
\dot{O} \\
\dot{q}\end{array}$ & \begin{tabular}{|l|}
$\infty$ \\
$\infty$ \\
10 \\
$\infty$ \\
$\infty$
\end{tabular} & $\begin{array}{l} \\
0 \\
\oplus \\
i 0 \\
\end{array}$ & 오․ & $\mid \begin{array}{l}\stackrel{2}{0} \\
\stackrel{2}{N} \\
\text { N }\end{array}$ & \\
\hline & & $\stackrel{\bar{N}}{\stackrel{\sim}{-}}$ & 艿 & $\begin{array}{l}\stackrel{Q}{N} \\
0\end{array}$ & $\begin{array}{l}8 \\
0 \\
0\end{array}$ & $\begin{array}{l}\infty \\
\sim \\
\infty \\
\infty\end{array}$ & $\mid \begin{array}{c}0 \\
\bar{i}\end{array}$ & $\begin{array}{l}\bar{L} \\
0 \\
0\end{array}$ & $\begin{array}{l}\infty \\
m \\
m\end{array} \mid$ & O্. & ָ̃ & $\check{c}_{\dot{m}}$ & $\stackrel{9}{\check{r}}$ & $\bar{\sigma}$ & $\mid \begin{array}{c}v \\
- \\
-\end{array}$ & ¿̣̊ & $\begin{array}{l}\mathscr{\Omega} \\
\dot{~ ๓ ं}\end{array}$ & 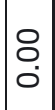 & ৪̀ & $\begin{array}{l}\hat{\rho} \\
\stackrel{\sigma}{\sigma}\end{array}$ & $\begin{array}{l}\stackrel{L}{\rho} \\
\dot{\sigma} \\
\dot{\gamma}\end{array}$ & $\begin{array}{l}\bar{o} \\
\grave{\sim}\end{array}$ & $\begin{array}{l}\mathscr{9} \\
\stackrel{\leftrightarrow}{\circ}\end{array}$ & $\left|\begin{array}{c}\mathbb{N} \\
\llcorner \\
\llcorner\end{array}\right|$ & 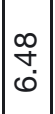 & 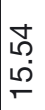 & $\mid \begin{array}{l}\hat{0} \\
\sigma^{\prime}\end{array}$ & \\
\hline & 5 & & $\begin{array}{l}0 \\
0 \\
0\end{array}$ & \begin{tabular}{l}
$\mathcal{O}$ \\
\hdashline \\
0
\end{tabular} & $\begin{array}{l}0 \\
0 \\
0\end{array}$ & $\begin{array}{l}\mathrm{O} \\
0 \\
0 \\
0\end{array}$ & $\begin{array}{c}0 \\
0 \\
0\end{array}$ & Oo & $\begin{array}{l} \\
0 \\
0^{\circ}\end{array}$ & ○े & Oo & $\begin{array}{l} \\
0 \\
0\end{array}$ & $\widetilde{O}$ & $\begin{array}{l}\theta \\
\dot{\circ} \\
\end{array}$ & 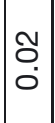 & $\begin{array}{l}\overline{0} \\
0 \\
0\end{array}$ & $\begin{array}{l}0 \\
0 \\
0\end{array}$ & $\begin{array}{l}\bar{\sigma} \\
0 \\
0\end{array}$ & $\begin{array}{l}5 \\
0 \\
0\end{array}$ & 足 & 움 & $\begin{array}{l}\tilde{O} \\
0 \\
\dot{0}\end{array}$ & $\frac{N}{\check{0}}$ & $\left|\begin{array}{l}0 \\
\hdashline \\
\hdashline\end{array}\right|$ & $\begin{array}{l}0 \\
\check{0}\end{array}$ & 离 & $\frac{\infty}{\tilde{0}}$ & \\
\hline & $\varepsilon$ & $\begin{array}{l}0 \\
0 \\
0\end{array}$ & $\begin{array}{l} \\
0 \\
0\end{array}$ & $\begin{array}{l}\tilde{N} \\
0 \\
0\end{array}$ & $\begin{array}{l}\Xi \\
0 \\
0\end{array}$ & $\begin{array}{l}0 \\
0 \\
0\end{array}$ & $\begin{array}{l}0 \\
0 \\
0\end{array} \mid$ & 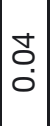 & $\mid \begin{array}{l}\infty \\
0 \\
0\end{array}$ & ס & o. & \begin{tabular}{l}
0 \\
0 \\
\hdashline
\end{tabular} & O̊ & ָָ & $\begin{array}{l} \\
0 \\
0\end{array}$ & $\begin{array}{l}\tilde{0} \\
0 \\
0\end{array}$ & 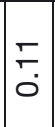 & $\begin{array}{l}0 \\
0 \\
0\end{array}$ & $\begin{array}{l}0 \\
0 \\
0 \\
0\end{array}$ & Oे & $\mid \begin{array}{l}0 \\
0 \\
0\end{array}$ & $\begin{array}{l}8 \\
0 \\
0\end{array}$ & $\frac{10}{0}$ & $\left|\begin{array}{l}\mid \\
0 \\
0\end{array}\right|$ & $\left|\begin{array}{l}\infty \\
0 \\
0\end{array}\right|$ & 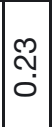 & $\frac{m}{0}$ & @ \\
\hline & $\begin{array}{l}1 \\
\varepsilon \\
\mathcal{D} \\
\varepsilon\end{array}$ & $\begin{array}{l}\infty \\
N \\
\infty \\
\stackrel{\infty}{N}\end{array}$ & $\mid \begin{array}{l}\infty \\
\infty \\
\dot{\dot{d}} \\
\mid\end{array}$ & 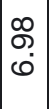 & $\mid \begin{array}{l}\infty \\
0 \\
0 \\
0 \\
\forall \\
\forall\end{array}$ & 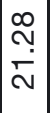 & $\begin{array}{c}\bar{N} \\
\stackrel{o}{o} \\
\dot{\gamma}\end{array}$ & $\mid \begin{array}{l}0 \\
0 \\
0 \\
\oplus \\
-\end{array}$ & $\mid \begin{array}{l}\stackrel{f}{q} \\
\stackrel{m}{N} \\
\stackrel{1}{n}\end{array}$ & $\begin{array}{l}\tilde{O} \\
\infty \\
\infty \\
\infty\end{array}$ & $\begin{array}{l}\infty \\
\infty \\
0 \\
0 \\
ల\end{array}$ & $\begin{array}{l}\cong \\
\infty \\
\stackrel{\infty}{\sim}\end{array}$ & $\frac{P}{\stackrel{p}{r}}$ & 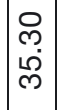 & $\mid \begin{array}{c}\infty \\
\stackrel{\sim}{\sim} \\
\stackrel{\sim}{+}\end{array}$ & 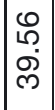 & $\mid \begin{array}{l}\infty \\
i \\
\stackrel{\infty}{\sim} \\
\sim\end{array}$ & 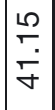 & $\mid \begin{array}{l}\stackrel{5}{0} \\
\dot{\square} \\
\dot{\gamma}\end{array}$ & 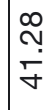 & $\left|\begin{array}{c}0 \\
0 \\
0 \\
\dot{q}\end{array}\right|$ & $\mid \begin{array}{l}\dot{J} \\
\dot{\infty} \\
\dot{\infty}\end{array}$ & \begin{tabular}{|l|}
2 \\
0 \\
$\mathscr{\rho}$ \\
$\sigma$
\end{tabular} & $\left|\begin{array}{c}1 \\
10 \\
15 \\
10\end{array}\right|$ & $\begin{array}{l}\hat{\partial} \\
\text { } \\
\delta\end{array}$ & 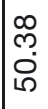 & $\left|\begin{array}{l}1 \\
0 \\
0 \\
10\end{array}\right|$ & \\
\hline & & $\vec{j}$ & $\begin{array}{c}0 \\
\stackrel{1}{ } \\
\infty\end{array} \mid$ & $\mid \begin{array}{l}\stackrel{2}{ } \\
\stackrel{1}{N}\end{array}$ & $\begin{array}{l}\qquad \\
\infty \\
\stackrel{\sim}{\infty} \\
\end{array}$ & $\frac{\infty}{\frac{\infty}{\infty}}$ & $\mid \begin{array}{c}\infty \\
\infty \\
\infty \\
\infty\end{array}$ & $\begin{array}{l}0 \\
0 \\
\infty\end{array}$ & $\mid \begin{array}{c}0 \\
N \\
\infty \\
\infty\end{array}$ & $\begin{array}{l}0 \\
\infty \\
\infty \\
\infty\end{array}$ & $\begin{array}{l}\text { गे } \\
\infty\end{array}$ & \begin{tabular}{|l}
10 \\
$\infty$ \\
$\infty$
\end{tabular} & $\frac{\infty}{\infty}$ & \begin{tabular}{|c|}
$\infty$ \\
$\infty$ \\
$\infty$ \\
$\infty$
\end{tabular} & $\begin{array}{l}\vec{j} \\
\infty \\
\infty\end{array}$ & \begin{tabular}{|l|}
$\infty$ \\
$\infty$ \\
$\infty$ \\
$\infty$
\end{tabular} & $\mid \begin{array}{l}\nabla \\
\infty \\
\infty\end{array}$ & $\begin{array}{l}1 \\
\infty \\
\infty \\
\infty\end{array}$ & \begin{tabular}{|c|}
$\infty$ \\
$\infty$ \\
$\infty$ \\
$\infty$
\end{tabular} & $\begin{array}{l}\text { ठ } \\
\infty \\
\infty\end{array}$ & 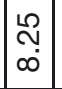 & $\begin{array}{l}m \\
\infty \\
\infty\end{array}$ & $\begin{array}{l}\hat{\sigma} \\
\infty \\
\infty\end{array}$ & $\left|\begin{array}{l}\mathbf{0} \\
\infty \\
\infty\end{array}\right|$ & $\begin{array}{l}1 \\
\infty \\
\infty\end{array}$ & 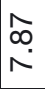 & 命 & \\
\hline & יד & & 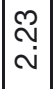 & & $\mid \begin{array}{l}0 \\
0 \\
-\end{array}$ & & $\stackrel{\mathscr{O}}{\stackrel{\leftrightarrow}{-}}$ & 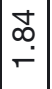 & 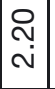 & 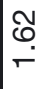 & $\stackrel{N}{\infty}$ & $\frac{10}{\grave{N}}$ & $\frac{\infty}{\stackrel{\infty}{r}}$ & $\begin{array}{l}\tilde{N} \\
\dot{c} \\
\dot{m}\end{array}$ & $\mid \begin{array}{l}\infty \\
0 \\
- \\
-\end{array}$ & 占 & $\left|\begin{array}{l}0 \\
0 \\
\ddot{n}\end{array}\right|$ & $\stackrel{\text { }}{\stackrel{\sim}{-}}$ & 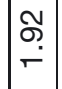 & ơ & চ্். & 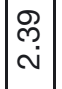 & $\begin{array}{c}\tilde{o} \\
\stackrel{\sim}{\sim}\end{array}$ & $\frac{\hat{n}}{\bar{N}}$ & $\begin{array}{l}0 \\
\infty \\
\dot{\sim}\end{array} \mid$ & $\hat{\stackrel{N}{O}}$ & $\begin{array}{l}0 \\
\tilde{N} \\
\dot{N}\end{array} \mid$ & \\
\hline & $\stackrel{\text { g }}{E}$ & $\begin{array}{l}\bar{\tau} \\
\dot{\tau} \\
\bar{\tau}\end{array}$ & 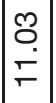 & $\mid \begin{array}{c}\stackrel{N}{N} \\
\bar{F}\end{array}$ & $\begin{array}{l}\hat{\jmath} \\
\bar{\tau} \\
\bar{r}\end{array}$ & $\mid \begin{array}{c}\tilde{N} \\
\stackrel{\tilde{p}}{\mp}\end{array}$ & $\begin{array}{l}\stackrel{m}{m} \\
\stackrel{+}{-}\end{array}$ & $\mid$\begin{tabular}{l}
0 \\
0 \\
0 \\
\hdashline
\end{tabular} & $\left|\begin{array}{l}\infty \\
0 \\
\dot{\rho} \\
\sim\end{array}\right|$ & $\stackrel{\stackrel{\sim}{N}}{\stackrel{\Gamma}{\leftarrow}}$ & 产 & $\mid \begin{array}{l}0 \\
0 \\
0 \\
0\end{array}$ & 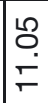 & 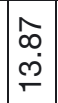 & $\mid \begin{array}{c}N \\
\\
0 \\
-\end{array}$ & 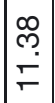 & $\mid \begin{array}{l}\infty \\
\stackrel{p}{\leftarrow} \\
\end{array}$ & 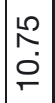 & $\mid$\begin{tabular}{l}
$\stackrel{0}{\Lambda}$ \\
$\stackrel{0}{0}$ \\
\hdashline
\end{tabular} & $\frac{n}{\sigma}$ & 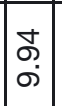 & 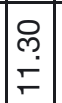 & $\mid \begin{array}{l}\infty \\
0 \\
\infty\end{array}$ & \begin{tabular}{|c|}
$\overline{1}$ \\
0 \\
0
\end{tabular} & $\left|\begin{array}{l}L \\
O \\
\end{array}\right|$ & Гొ & $\mid \begin{array}{l}0 \\
0 \\
0 \\
-\end{array}$ & $\begin{array}{l}\infty \\
\infty \\
\infty\end{array}$ \\
\hline & $\varepsilon$ & $\begin{array}{l}\infty \\
1 \\
0 \\
0\end{array}$ & $\hat{\mathscr{\theta}}$ & ৪ & న్లి & 웅 & $\begin{array}{l}9 \\
\dot{0} \\
10\end{array}$ & $\frac{N}{N}$ & 웅 & 果 & 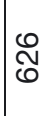 & $\overline{\widetilde{N}}$ & $\underset{5}{5}$ & ్ㅠ & 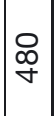 & $\stackrel{8}{\infty}$ & 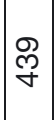 & $\mid \begin{array}{c}\mathbb{N} \\
\hat{N} \\
\kappa\end{array}$ & 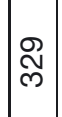 & 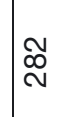 & in & ల్ల & $\stackrel{\mathscr{N}}{\tilde{N}}$ & $\stackrel{\mathbb{N}}{\stackrel{N}{*}}$ & $\stackrel{\stackrel{0}{f}}{\sim}$ & 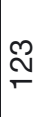 & $\stackrel{0}{\div}$ & 음 \\
\hline & $z$ & 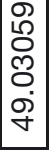 & 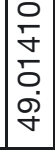 & 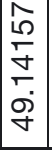 & 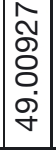 & 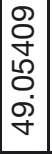 & 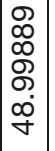 & 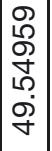 & $\mid \begin{array}{c}\text { O } \\
\dot{0} \\
\text { J } \\
\text {. } \\
\text { g. }\end{array}$ & 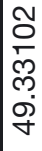 & 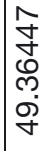 & 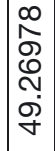 & 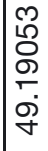 & 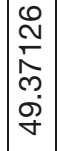 & 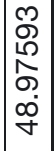 & 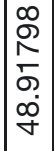 & 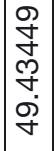 & 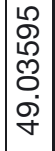 & 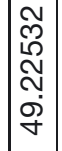 & $\begin{array}{l}\frac{1}{2} \\
\infty \\
m \\
\square \\
\sigma \\
\text { g. }\end{array}$ & $\left|\begin{array}{c}0 \\
\mathbb{N} \\
\delta \\
0 \\
0 \\
\infty \\
\dot{q}\end{array}\right|$ & 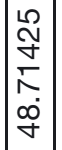 & 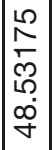 & 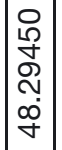 & 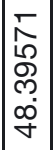 & 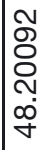 & $\left|\begin{array}{c}\bar{\sim} \\
\infty \\
\stackrel{\sim}{\sim} \\
\underset{\sim}{\infty} \\
\stackrel{+}{+}\end{array}\right|$ & 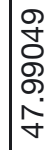 \\
\hline & ш & $\mid \begin{array}{l}\infty \\
\infty \\
\infty \\
\infty \\
\infty \\
N \\
\infty \\
\Gamma\end{array}$ & 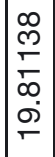 & 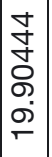 & 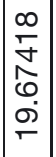 & 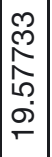 & 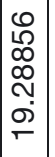 & $\left|\begin{array}{l}\hat{\alpha} \\
\frac{1}{\sigma} \\
\bar{f} \\
0\end{array}\right|$ & 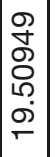 & 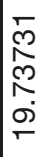 & 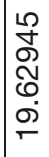 & 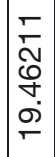 & $\begin{array}{l}\frac{m}{N} \\
\frac{\sigma}{\sigma} \\
\frac{\sigma}{\sigma}\end{array}$ & 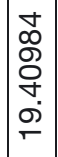 & $\mid \begin{array}{l}\infty \\
\infty \\
0 \\
\infty \\
\infty \\
\infty \\
\square\end{array}$ & 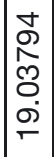 & $\mid \begin{array}{l}\infty \\
\tilde{N} \\
\stackrel{N}{N} \\
\infty \\
\sim\end{array}$ & $\mid \begin{array}{l}0 \\
0 \\
0 \\
0 \\
\infty \\
\infty\end{array}$ & 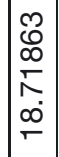 & \begin{tabular}{l}
$\sim$ \\
$\sim$ \\
$\mathcal{Y}$ \\
0 \\
\multirow{1}{*}{} \\
$\infty$ \\
$\sim$
\end{tabular} & 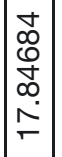 & 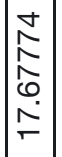 & 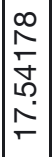 & 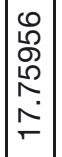 & 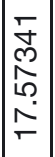 & 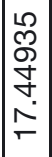 & 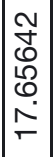 & 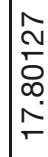 \\
\hline
\end{tabular}

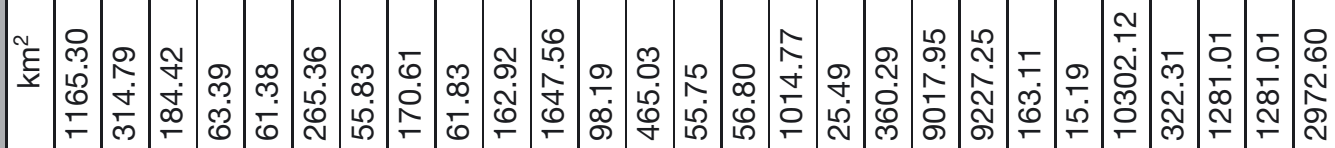




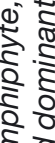

हึ่

$\frac{\pi}{\frac{\pi}{2}}$

范资

近 $N$

है

을

동

(1)

के

oे

ఖ $\frac{0}{9}$

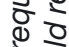

난 은

L.

तें

ฐึ

ह

वे

0 ब

ปे के

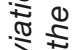

बे

के

क के

ปิ

đ现

1 है

อे है

एक षै

ะ จ

\begin{tabular}{|c|c|c|c|c|c|c|c|c|c|c|c|c|c|c|c|c|c|c|c|c|c|}
\hline 홍 & $\frac{\rho}{0}$ & ৯ & 号 & $\underset{\aleph}{\stackrel{亠}{~}}$ & $\Sigma$ & $\mp$ & 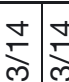 & 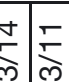 & $\lesssim$ & হ্লা & $\mp$ & & $\lesssim$ & $\bar{\Sigma}$ & 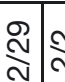 & $\begin{array}{c}\text { Na } \\
\text { Ne }\end{array}$ & $\frac{\Gamma}{\text { s }}$ & $\left|\begin{array}{l}\stackrel{0}{\mathrm{~N}} \\
\mathrm{~N}\end{array}\right|$ & $\stackrel{N}{N}$ & $\delta$ & $\Sigma)$ \\
\hline & & & & & $\Sigma$ & & 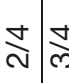 & 迥 & $\bar{\aleph}$ & & & & & & 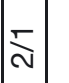 & & & & & & \\
\hline
\end{tabular}

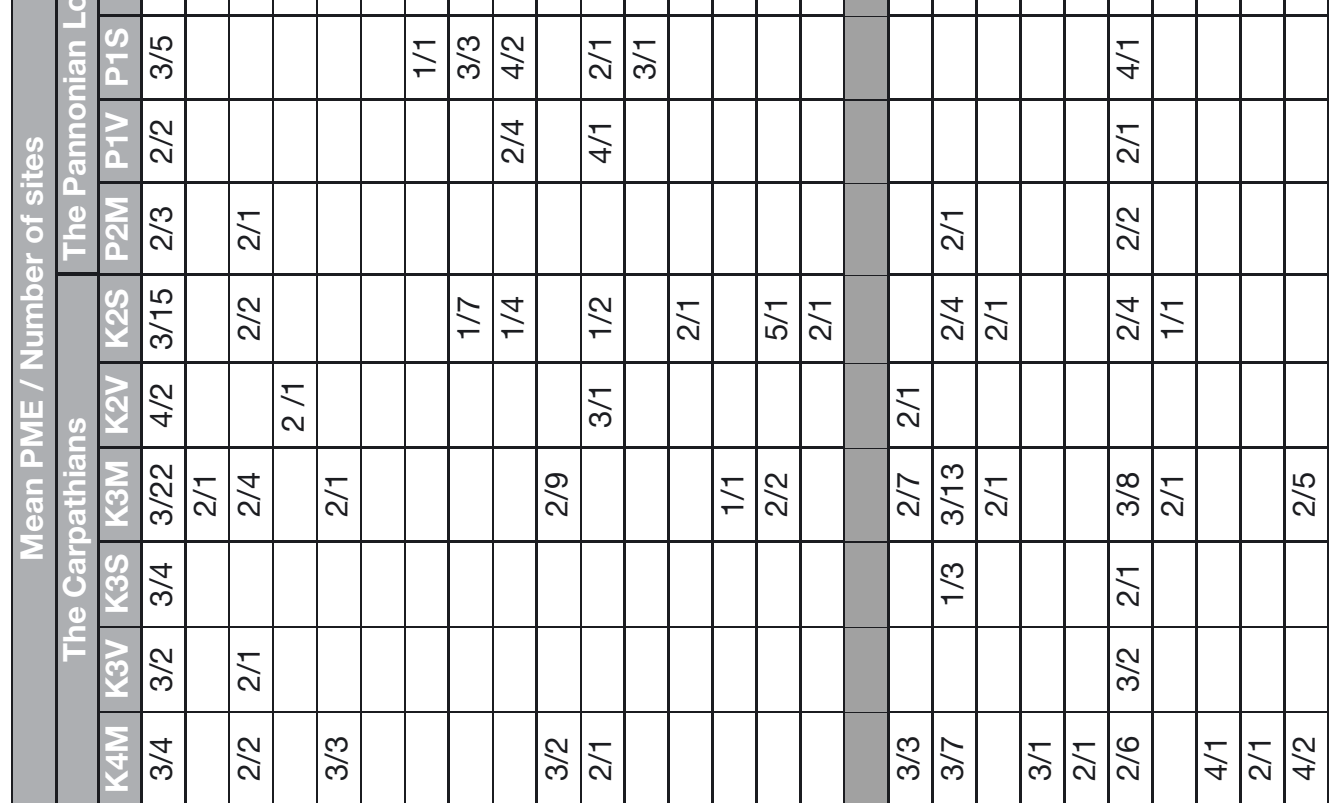

๑

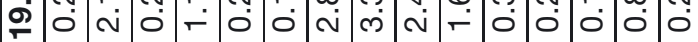

হ

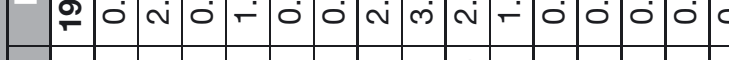

S)

車

ヘิ

要这

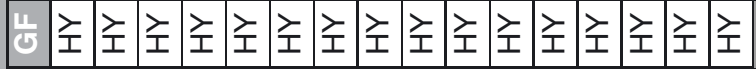

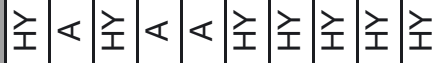

가 0.5

ชू

के है

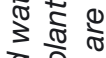

일

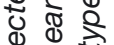

ळ $ह$

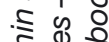

紊市

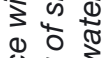

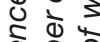

ब 0 व

ริ

$0<$

$\circ$ 出

व $\sum_{0}$

(ब)

ชา ฮิ

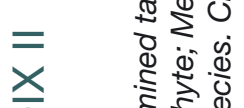

हो टे

$-\frac{10}{2}$

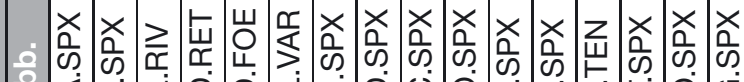

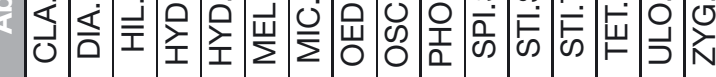

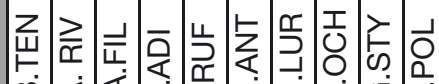
ற்

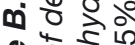

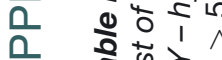

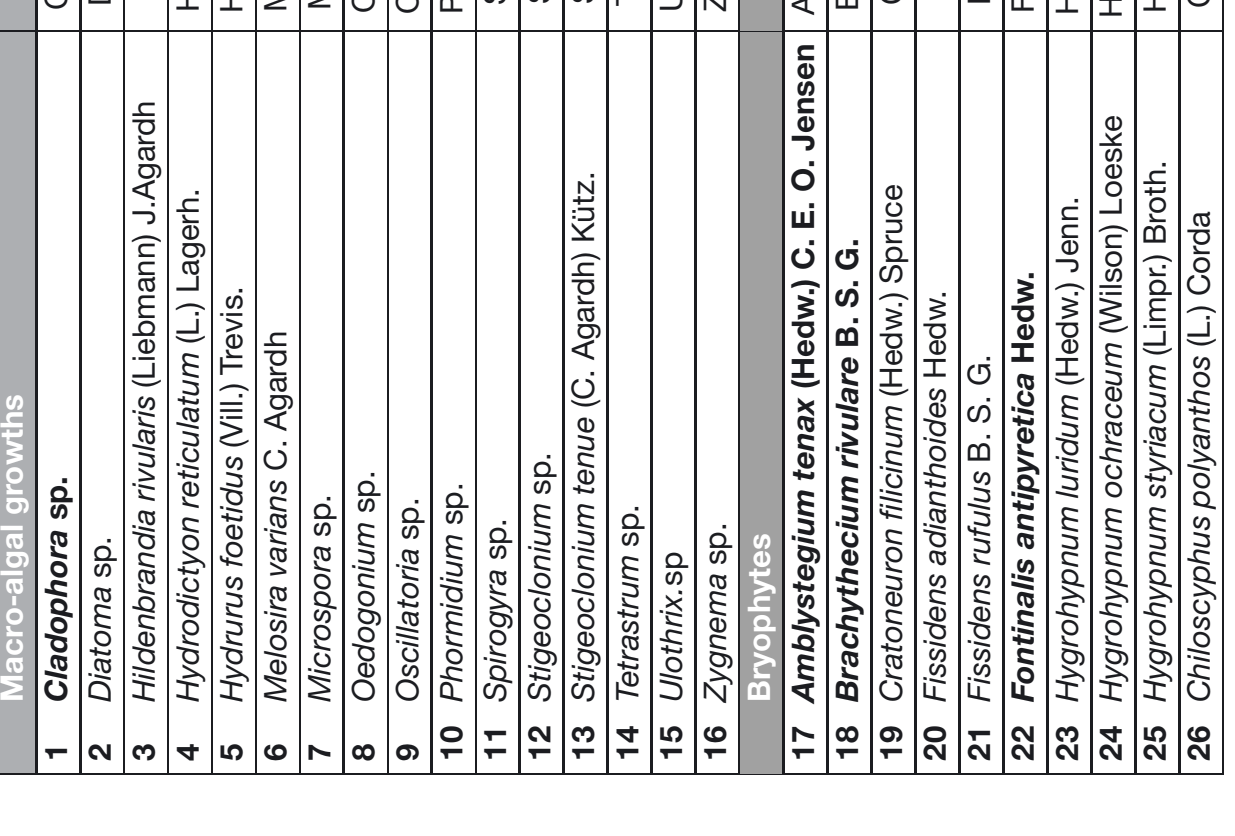




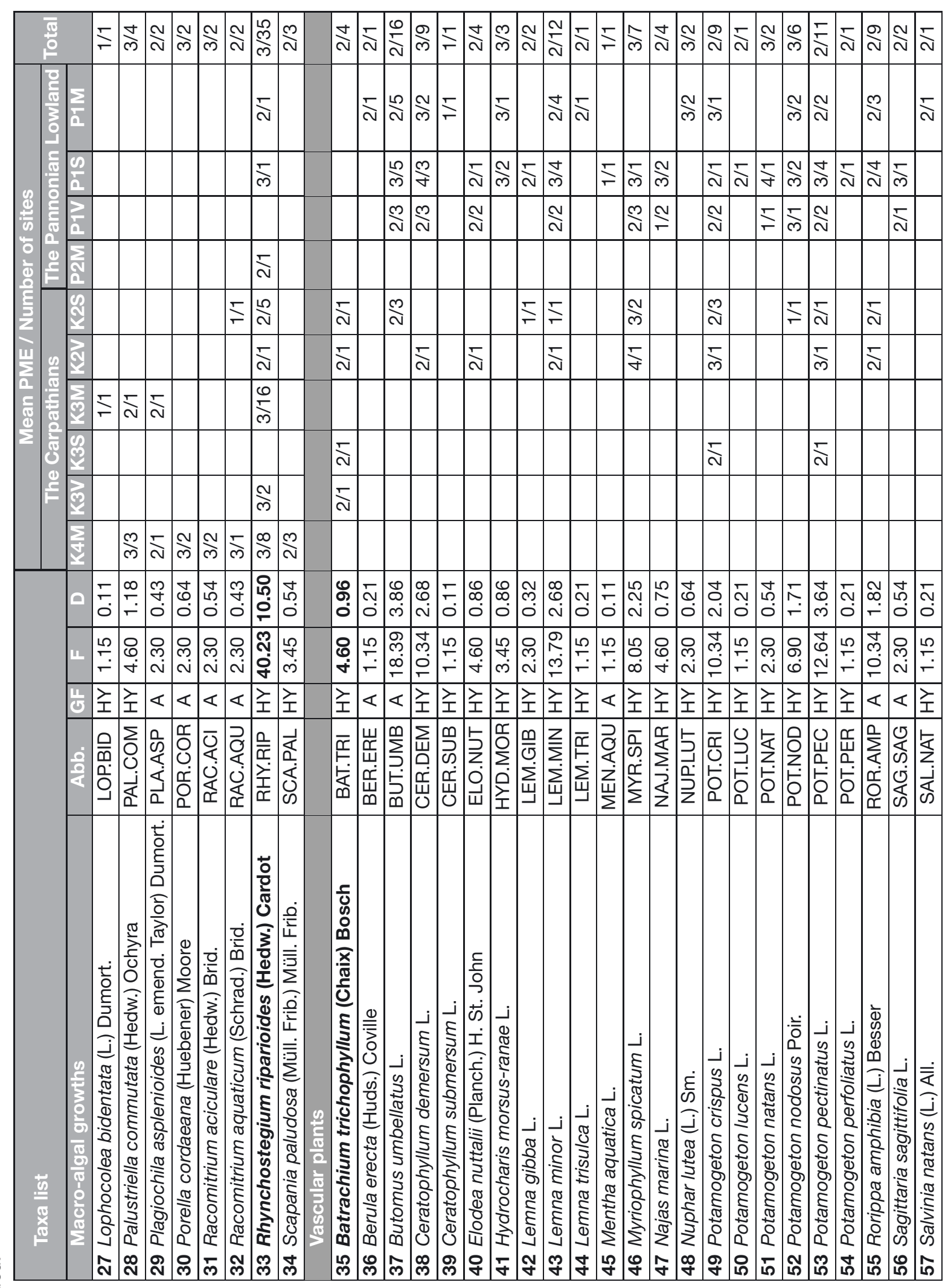




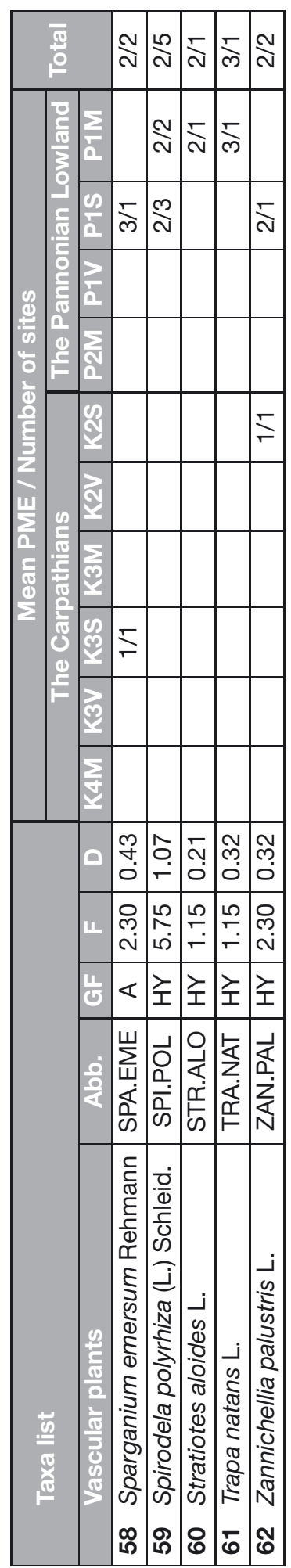

ن 


\section{REFERENCES}

Baattrup-Pedersen A., Szoszkiewicz K., Nijboer R., O’Hare M.O. and Ferreira T., 2006. Macrophyte communities in unimpacted European streams: variability in assemblage patterns, abundance and diversity. Hydrobiologia, 566, 179-196.

Baláži P. and Tóthová L., 2010a. Ecological status based on aquatic macrophytes in selected water bodies in the Danube catchment area (Slovakia). Zborník Východoslov. Múzea. Natura Carpatica (Košice), 51, 7-17.

Baláži P. and Tóthová L., 2010b. Využitie IBMR (Macrophyte Biological Index for Rivers) pre hodnotenie ekologického stavu vodných útvarov podl'a vodných makrofytov. Acta Envir. Univ. Comenianae (Bratislava), 18/2, 47-62.

Baláži P., Mišíková K. and Tóthová L., 2010. Machorasty ako súčasti spoločenstva vodných makrofytov na vybraných monitorovaných lokalitách tečúcich vôd Slovenska. Acta Envir. Univ. Comenianae (Bratislava), 18/2, 63-78.

Baláži P., Tóthová L., Ot'ahel'ová H., Hrivnák R. and Mišíková K., 2011. Checklist of taxa examined at localities monitored in the Slovak surface water bodies - macrophytes. Acta Envir. Univ. Comenianae (Bratislava), 19/1, 5-89.

Baláži P., Hrivnák R. and Ot'ahel'ová H., 2014. The relationship between macrophyte assemblages and selected environmental variables in reservoirs of Slovakia examined for the purpose of ecological assessment. Pol. J. Ecol., 62, 541-558.

Birk S. and Willby N., 2010. Towards harmonization of ecological quality classification: establishing common grounds in European macrophyte assessment for rivers. Hydrobiologia, 652, 149-163.

Ceschin S., Aleffi M., Bisceglie S., Savo V. and Zuccarello V., 2012. Aquatic bryophytes as ecological indicators of the water quality status in the Tiber River basin (Italy). Ecol. Indic., 14, 74-81.

Dawson F.H., Newman J.R., Gravelle M.J., Rouen K.J. and Henville P., 1999. Assessment of the Trophic Status of Rivers using Macrophytes: Evaluation of the Mean Trophic Rank. R\&D Technical Report E39, Environment Agency of England \& Wales, Bristol, UK.

Dodds W.K. and Gudder D.A., 1992. The ecology of Cladophora. J. Phycol., 28, 415-427.

Dodkins I., Rippey B. and Hale P., 2005. An application of canonical correspondence analysis for developing ecological quality assessment metrics for river macrophytes. Freshwater Biol., 50, 891-904.

Downes B.J., Entwisle T.J. and Reich P., 2003. Effects of flow regulation on disturbance frequencies and in-channel bryophytes and macroalgae in some upland streams. River Res. Appl., 19, 27-42.

EN 14184: 2014. Water quality. Guidance Standard for the Surveying of Aquatic Macrophytes in Running Waters. European Committee for Standardization, Brussels, 14 p.

European Environmental Agency, 2000. Coordination of Information on the Environment - Land Cover 2000.

European Union, 2000. Directive /2000/60/EC of the European Parliament and of the Council of 23 October 2000 establishing a framework for Community action in the field of water policy. Official Journal of the European Communities. L 327/1. 22.12.2000, 1-72.

Ferreira M.T. and Moreira I.S., 1999. River plants from an Iberian basin and environmental factors influencing their distribution. Hydrobiologia, 415, 101-107.

Franklin P., Dunbar M. and Whitehead P., 2008. Flow controls on lowland river macropyhtes: A review. Sci. Total Environ., 40, 369-378.

Gecheva G., Cheshmedjiev S., Dimitrova-Dyulgerova I., Belkinova D. and Mladenov R., 2010. Implementation and adaptation of macrophyte indication system: assessment of ecological status of rivers in Bulgaria according to the Water Framework Directive. Biotechnology \& Biotechnological Equipment 24, 171-180.

Haslam S.M., 2006. River Plants (revised second edition). Forrest Text, Ceredigion, 438 p.

Haury J., Peltre M.C., Termolieres M., Barbe J., Thiebaut G., Bernez I., Daniel H., Chatenet P., HaanArchipof G., Muller S., Dutartre A., Laplace-Treyture C., Cazaubon A. and Lambert-Servien E., 2006. A new method to assess water trophy and organic pollution: the Macrophyte Biological Index for Rivers (IBMR) its application to different types of river and pollution. Hydrobiologia, 570, 153-158.

Hrivnák R., Valachovič M. and Ripka J., 2003. Relation between macrophyte vegetation and environmental condition in the Ipel' River (Slovakia) - case study. Arch. Hydrobiol., Suppl. 147/1-2, 117127. 
Hrivnák R., Ot'ahel'ová H. and Valachovič M., 2007. The relationship between macrophyte vegetation and habitat factors along a middle-size European river. Pol. J. Ecol., 55, 717-729.

Hrivnák R., Ot'ahel'ová H., Valachovič M., Pal'ove-Balang P. and Kubinská A., 2010. Effect of environmental variables on the aquatic macrophyte composition pattern in streams: a case study from Slovakia. Fundam. Appl. Limnol., Suppl. 177/2, 115-124.

Hrivnák R., Ot'ahel'ová H., Kochjarová J. and Pal'ove-Balang P., 2013. Effect of environmental conditions on species composition of macrophytes - study from two distinct biogeographical regions of Central Europe. Knowl. Manag. Aquat. Ecosyst., 411, 09

Janauer G.A., 2003. Methods. In: Janauer G.A., Hale P. and Sweeting R. (eds.), Macrophyte inventory of the river Danube: A pilot study, Arch. Hydrobiol., 14, 9-16.

Janauer G.A. and Dokulil M., 2006. Macrophytes and Algae in Running Waters. In: Ziglio G., Siligardi M. and Flaim G. (eds.), Biological Monitoring of Rivers. John Wiley \& Sons, 89-109.

Kelly M., 2013. Data rich, information poor? Phytobenthos assessment and the Water Framework Directive, Eur. J. Phycol., 48/4, 437-450.

Kuhar U., Germ M., Gaberščik A. and Urbanič G., 2011. Development of a River Macropyhte Index (RMI) for assessing river ecological status. Limnologica, 41, 235-243.

Lacoul P. and Freedman B., 2006. Environmental influences on aquatic plants in freshwater ecosystems. Environ. Rev., 14, 89-136.

Leyssen A., Adriaens P., Denys L., Packet J., Schneiders A., Van Looy K. and Vanhecke L., 2005. Toepassing van verschillende biologische beoordelingssystemen op Vlaamse potentiële interkalibratielocaties overeenkomstig de Europese kaderrichtlijn water: partim 'Macrofyten'. Instituut voor Natuurbehoud, Brussel, $178 \mathrm{p}$.

Luis L., Bergamini A. and Sim-Sim M., 2015. Which environmental factors best explain variation of species richness and composition of stream bryophytes? A case study from mountainous streams in Medeira Island. Aquat. Bot., 123, 37-46.

Manolaki P. and Papastergiadou E., 2015. Environmental Factors Influencing Macrophytes Assemblages in a Middle-Sized Mediterranean Stream. River Res. Appl., DOI: 10.1002/rra.2878.

Marhold K. and Hindák F., 1998. Checklist of non-vascular and vascular plants of Slovakia. Veda, Bratislava, $688 \mathrm{p}$.

Ministry of Environment of the Slovak Republic. 2011. Water Plan of the Slovak Republic - Abbreviated version, $124 \mathrm{p}$.

NF T90-395: 2003. Water quality. Determination of the Macrophyte Biological Index for Rivers (IBMR). Association Française de Normalisation (AFNOR), Saint Denis La Plaine, 28 p.

NV SR 269/2010 Z. z., v znení neskorších predpisov. Nariadenie vlády Slovenskej republiky, ktorým ktorým sa ustanovujú požiadavky na dosiahnutie dobrého stavu vôd.

Ot'ahel'ová H., Hrivnák R., Valachovič M. and Janaur G.A., 2007a. Temporal changes of aquatic macrophyte vegetation in a lowland groundwater feed eutrophic course (Klátovské rameno, Slovakia). Acta Soc. Bot. Poloniae, 76, 141-150.

Ot'ahel'ová H., Valachovič M. and Hrivnák R., 2007b. The impact of environmental factors on the distribution pattern of aquatic plants along the Danube River corridor (Slovakia). Limnologica, 37, 290-302.

Papastergiadou E., Stefanidis K., Dorflinger G., Giannouris E., Kostrata K. and Manolaki P., 2015. Exploring biodiversity in riparian corridors of a Mediterranean island: Plant communities and environmental parameters in Cyprus. Plant Biosyst. (in press), http://dx.doi.org/10.1080/11263504. 2014.941032.

Schneider S.C., Lawniczak A.E., Piciñska-Faltynowicz J. and Szoszkiewicz K., 2012. Do macropyhtes, diatoms and non-diatom benthic algae give redundant information? Results from a case study in Poland. Limnologica, 42, 204-211.

StatSoft Inc. 2011. STATISTICA for Windows [Computer program Manual] Tulsa, OK: StatSoft Inc., 2300 Tulsa, http://www.stat.soft.com

Szoszkiewicz K., Ferreira T., Korte T., Baatrup-Pedersen A., Davy-Bowker J. and O'Hare M., 2006. European river plant communities: the importance of organic pollution and the usefulness of existing macrophyte metrics. Hydrobiologia, 566, 21-234.

Szoszkiewicz K., Kayzer D., Staniszewski R. and Dawson H.F., 2010. Measures of central tendency of aquatic habitat parameters: Application to river macrophyte communities. Pol. J. Ecol., 58, 693706. 
Szoszkiewicz K., Ciecierska H., Kolada A., Schneider S.C., Szwabinska M. and Ruszczynska J., 2014. Parameters structuring macrophyte communities in rivers and lakes - results from a case study in North-Central Poland. Knowl. Manag. Aquatic Ecosyst., 415, 08

ter Braak C.J.F. and Šmilauer P., 2012. CANOCO reference manual and user's guide: software for ordination (version 5.0), Microcomputer Power, Ithaca, NY, $496 \mathrm{p}$.

Ward J.V., Tockner K., Arscott D.B. and Claret C., 2002. Riverine landscape diversity. Freshwater Biol., 47, 517-539.

Willby N., Pitt J.A. and Phillips G., 2009. The Ecological Classification of UK Rivers Using Aquatic Macrophytes. Environment Agency, Science Report.

Žuna Pfeiffer T., Mihaljević M., Špoljarić D., Stević F. and Plenković-Moraj A., 2015. The disturbancedriven changes of periphytic algal communities in a Danubian floodplain lake. Knowl. Manag. Aquat. Ecosyst., 416, 02.

Cite this article as: P. Baláži and R. Hrivnák, 2015. Bryophytes and macro-algal growths as a part of macrophyte monitoring in rivers used for ecological assessment. Knowl. Manag. Aquat. Ecosyst., $416,19$. 